\title{
Observations of ozone production in a dissipating tropical convective cell during TC4
}

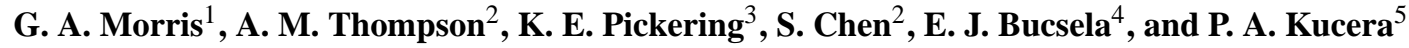 \\ ${ }^{1}$ Dept. of Physics and Astronomy, Valparaiso University, Valparaiso, IN, USA \\ ${ }^{2}$ Dept. of Meteorology, Pennsylvania State University, University Park, PA, USA \\ ${ }^{3}$ Atmospheric Chemistry and Dynamics Branch, Laboratory for Atmospheres, NASA Goddard Space \\ Flight Center, Greenbelt, MD, USA \\ ${ }^{4}$ SRI International, Menlo Park, CA, USA \\ ${ }^{5}$ Research Applications Laboratory, NCAR, Boulder, CO, USA
}

Received: 10 July 2010 - Published in Atmos. Chem. Phys. Discuss.: 11 August 2010

Revised: 10 November 2010 - Accepted: 11 November 2010 - Published: 26 November 2010

\begin{abstract}
From 13 July-9 August 2007, 25 ozonesondes were launched from Las Tablas, Panama as part of the Tropical Composition, Cloud, and Climate Coupling (TC4) mission. On 5 August, a strong convective cell formed in the Gulf of Panama. World Wide Lightning Location Network (WWLLN) data indicated 563 flashes (09:00-17:00 UTC) in the Gulf. $\mathrm{NO}_{2}$ data from the Ozone Monitoring Instrument (OMI) show enhancements, suggesting lightning production of $\mathrm{NO}_{\mathrm{x}}$. At 15:05 UTC, an ozonesonde ascended into the southern edge of the now dissipating convective cell as it moved west across the Azuero Peninsula. The balloon oscillated from 2.5-5.1 km five times (15:12-17:00 UTC), providing a unique examination of ozone $\left(\mathrm{O}_{3}\right)$ photochemistry on the edge of a convective cell. Ozone increased at a rate of $\sim 1.6-4.6 \mathrm{ppbv} / \mathrm{hr}$ between the first and last ascent, resulting cell wide in an increase of $\sim(2.1-2.5) \times 10^{6}$ moles of $\mathrm{O}_{3}$. This estimate agrees to within a factor of two of our estimates of photochemical lightning $\mathrm{O}_{3}$ production from the WWLLN flashes, from the radar-inferred lightning flash data, and from the $\mathrm{OMI} \mathrm{NO}_{2}$ data $\left(\sim 1.2, \sim 1.0\right.$, and $\sim 1.7 \times 10^{6}$ moles, respectively), though all estimates have large uncertainties. Examination of DC-8 in situ and lidar $\mathrm{O}_{3}$ data gathered around the Gulf that day suggests $70-97 \%$ of the $\mathrm{O}_{3}$ change occurred in $2.5-5.1 \mathrm{~km}$ layer. A photochemical box model initialized with nearby TC4 aircraft trace gas data suggests these $\mathrm{O}_{3}$ production rates are possible with our present understanding of photochemistry.
\end{abstract}

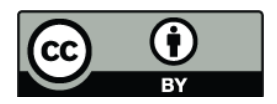

Correspondence to: G. A. Morris (gary.morris@valpo.edu)

\section{Introduction}

Numerous studies in the latter half of the 20-th Century have examined the role of lightning in global and regional ozone $\left(\mathrm{O}_{3}\right)$ (e.g., Kroening and Ney, 1962; Orville, 1967; Griffing, 1977; Levine, et al., 1981; Pickering et al., 1990; Lelieveld and Crutzen, 1994; Lawrence et al., 2003; Doherty et al., 2005; Cooper et al., 2006; see also Table 1) and in particular, its photochemical production resulting from lightning-produced reactive nitrogen $\left(\mathrm{NO}_{\mathrm{x}}\right)$ (Noxon, 1976; Chameides et al., 1977, 1979; Peyrous and Lepeyre, 1982). With refinements in regional and global models and lightning flash data from satellites and ground-based networks, the global lightning $\mathrm{NO}_{\mathrm{x}}\left(\mathrm{LtNO}_{\mathrm{x}}\right)$ budget has been reliably set at 2-8 Tg N/year (Pickering et al., 2009; Schumann and Huntrieser, 2007; Lawrence et al., 1995). Photochemical reactions involving $\mathrm{LtNO}_{\mathrm{x}}$ lead to $\mathrm{O}_{3}$ formation. Grewe (2007) estimates the global lightning contribution to tropospheric $\mathrm{O}_{3}$ at $>30 \%$, with the fractional source greatest in the tropics.

Laboratory studies have suggested that direct production of $\mathrm{O}_{3}$ occurs mainly during the pre-discharge period of storms (Peyrous and Lapeyre, 1982), and Franzblau (1991) found (1) little $\mathrm{O}_{3}$ production except at very low energies, (2) large decreases in $\mathrm{O}_{3}$ immediately after discharges, and (3) nearly full recovery to pre-discharge levels after $\sim 10 \mathrm{~min}$ (see his Fig. 1).

A number of field campaigns and modeling studies have attempted to identify the role of lightning in the formation and/or destruction of tropospheric ozone, and the role of convective activity in the redistribution of $\mathrm{NO}_{\mathrm{x}}, \mathrm{O}_{3}$, and other trace species within the troposphere. The results from these

Published by Copernicus Publications on behalf of the European Geosciences Union. 
Table 1. Summary of previous studies of $\mathrm{O}_{3}$ production.

\begin{tabular}{|c|c|c|c|}
\hline Observation & Location & Instrument/Model & Citation \\
\hline $\begin{array}{l}\mathrm{O}_{3} \text { aloft }=2-3 \times \\
\text { pre-storm surface } \mathrm{O}_{3} .\end{array}$ & New Mexico & Ozonesonde & $\begin{array}{l}\text { Schlanta } \\
\text { and Moore (1972) }\end{array}$ \\
\hline $\begin{array}{l}+300 \text { ppbv of } \mathrm{O}_{3} \text { near } \\
1 \mathrm{~km} \text { in thunderstorm }\end{array}$ & Maryland & Aircraft & Clark and Griffing (1985) \\
\hline $\begin{array}{l}\text { Peak } \mathrm{O}_{3} \text { detected at } 5 \mathrm{~km} \text {, } \\
\text { secondary peak at } 10 \mathrm{~km}\end{array}$ & Midwest USA & $\begin{array}{l}\text { Aircraft (PRE-STORM } \\
\text { project) }\end{array}$ & Dickerson et al. (1987) \\
\hline $\begin{array}{l}\text { The highest } \mathrm{O}_{3} \text { produc- } \\
\text { tion potential found below } \\
5 \mathrm{~km} \text { following deep con- } \\
\text { vection; dissipating cell } \\
7-17 \mathrm{ppbv} / \text { day @ } 1-6 \mathrm{~km} \\
\text { (their Fig. 14) }\end{array}$ & $\begin{array}{l}\text { South Central } \\
\text { USA }\end{array}$ & $\begin{array}{l}\text { Aircraft (PRE-STORM) + } \\
\text { 1-D photochemical model }\end{array}$ & Pickering et al. (1990) \\
\hline $\begin{array}{l}\text { Convection enhances } \\
\mathrm{O}_{3}<6.5 \mathrm{~km} \text { at } 5^{\circ} \mathrm{N} \\
\text { (their Fig. 1) }\end{array}$ & Global analysis & Global 3-D model & $\begin{array}{l}\text { Lelieveld and } \\
\text { Crutzen (1994) }\end{array}$ \\
\hline $\begin{array}{l}7-8 \text { ppbv/day of } \mathrm{O}_{3} \text { pro- } \\
\text { duced downwind of } \\
\text { thunderstorms at } 8-12 \mathrm{~km}\end{array}$ & Brazil & $\begin{array}{l}\text { DC-8, Ozonesondes + } \\
\text { GCE model }\end{array}$ & $\begin{array}{l}\text { Pickering et al. (1996) and } \\
\text { Thompson et al. (1997) }\end{array}$ \\
\hline $\begin{array}{l}\text { Most } \mathrm{LtNO}_{\mathrm{x}} \text { is produced } \\
\text { below } 5 \mathrm{~km} \text { by CG flashes }\end{array}$ & Global analysis & $\begin{array}{l}\text { International Satellite } \\
\text { Cloud Climatology } \\
\text { Project }\end{array}$ & Price et al. (1997) \\
\hline $\begin{array}{l}+38 \mathrm{ppbv} \mathrm{O}_{3} \text { in convective } \\
\text { cloud }\end{array}$ & France & $\begin{array}{l}\text { DOAS + GOMETRAN } \\
\text { model }\end{array}$ & Winterrath et al. (1999) \\
\hline $\begin{array}{l}+12 \% \text { of tropospheric } \mathrm{O}_{3} \\
\text { due to convection }\end{array}$ & Global analysis & MATCH-MPIC model & Lawrence et al. (2003) \\
\hline $\begin{array}{l}10-20 \% \text { of tropospheric } \\
\mathrm{O}_{3} \text { from lightning at 2- } \\
6 \mathrm{~km} ; 20-30 \% \text { at } 6-12 \mathrm{~km} \\
\text { @ } \sim 10^{\circ} \mathrm{N} \text {. }\end{array}$ & Global analysis & MOZART model & Zhang et al. (2003) \\
\hline $\begin{array}{l}+2 \text { ppbv of } \mathrm{O}_{3} \text { during } \\
\text { storm, }+10 \mathrm{ppbv} / 24 \mathrm{~h} \\
\text { in UT }(5-10 \mathrm{~km})\end{array}$ & $\begin{array}{l}\text { USA high } \\
\text { plains }\end{array}$ & $\begin{array}{l}\text { STERAO-A + CSCTM } \\
\text { and GCE models }\end{array}$ & DeCaria et al. (2005) \\
\hline $\begin{array}{l}\text { In the tropics, convection } \\
\text { reduces } \mathrm{O}_{3} \text { by } 1-3 \text { ppbv } \\
<1.5 \mathrm{~km} \text { and increases } \\
\mathrm{O}_{3} \text { by } 1-5 \text { ppbv from } 1.5- \\
5.5 \mathrm{~km} \text { (Fig. } 3 \text { ), but glob- } \\
\text { ally, convection reduces } \\
\text { tropospheric } \mathrm{O}_{3} \text { by } 13 \% \text {. }\end{array}$ & Global analysis & STOCHEM-HadAM3 & Doherty et al. (2005) \\
\hline $\begin{array}{l}80 \% \text { of } \mathrm{O}_{3} \text { above back- } \\
\text { ground due to } \mathrm{LtNO}_{\mathrm{x}} \\
\mathrm{P}\left(\mathrm{O}_{3}\right)=+3-4 \text { ppbv/day; } \\
16-24 \text { ppbv } \mathrm{O}_{3} \text { in UT }\end{array}$ & $\begin{array}{l}\text { Southeast USA } \\
\text { and Texas }\end{array}$ & $\begin{array}{l}\text { Ozonesondes (IONS-04) } \\
\text { + Flexpart model }\end{array}$ & Cooper et al. (2006) \\
\hline $\begin{array}{l}6-8 \text { ppbv lower } \mathrm{O}_{3} \text { in con- } \\
\text { vective cell }\end{array}$ & Tropical Pacific & Aircraft (PEM-Tropics B) & Ridley et al. (2006) \\
\hline $\begin{array}{l}\mathrm{LtNO}_{\mathrm{x}} \text { leads to }+25- \\
30 \mathrm{ppbv} \text { of } \mathrm{O}_{3} @ 10 \mathrm{~km}\end{array}$ & Southeast USA & $\begin{array}{l}\text { Ozonesondes (IONS-06) } \\
\text { + Flexpart model }\end{array}$ & Cooper et al. (2007) \\
\hline $\begin{array}{l}+10-15 \mathrm{DU} \text { of } \mathrm{O}_{3} \text { down- } \\
\text { wind of convection } \\
\text { and biomass burning }\end{array}$ & Tropical Atlantic & SCIAMACHY & Martin et al. (2007) \\
\hline
\end{tabular}

studies vary widely, with some suggesting strong enhancements of $\mathrm{O}_{3}$ (e.g., Schlanta and Moore, 1972; Dickerson et al., 1987) and others suggesting no such enhancements and potential losses of $\mathrm{O}_{3}$ (e.g., Ridley et al., 2006; Ott et al., 2007; Salzmann et al., 2008). Results from these previous studies are summarized in Table 1.
The TC4 campaign (Toon et al., 2010) was an excellent vehicle to further investigate wave activity, lightning, and $\mathrm{O}_{3}$ responses in a highly-convective environment, closer to the Intertropical Convergence Zone than the AugustSeptember Intercontinental Transport Experiment (INTEX)B Ozonesonde Network Study (IONS-06) soundings (e.g., 
Table 1. Continued.

\begin{tabular}{|c|c|c|c|}
\hline Observation & Location & Instrument/Model & Citation \\
\hline $\begin{array}{l}9 \text { ppbv lower } \mathrm{O}_{3} \text { during } \\
3 \mathrm{~h} \text { of storm, } \\
\text { but }+5 \text { ppbv/day } \\
\text { downwind @ } 5.5 \mathrm{~km}\end{array}$ & Europe & $\begin{array}{l}\text { European Lightning } \\
\text { Nitrogen Oxides Project } \\
\text { + GCE model }\end{array}$ & Ott et al. (2007) \\
\hline $\begin{array}{l}+7 \mathrm{DU} \text { of } \mathrm{O}_{3} ; 80 \% \mathrm{O}_{3} \\
\text { from storms @ } 2.5-10 \mathrm{~km}\end{array}$ & Tropical Atlantic & $\begin{array}{l}\text { Ozonesondes + } \\
\text { LIS + RegCM3 model }\end{array}$ & Jenkins et al. (2008) \\
\hline $\begin{array}{l}\text { Direct production of } 0.2- \\
2.0 \times 10^{27} \text { molecules } \mathrm{O}_{3} \\
\text { per flash; mechanism pro- } \\
\text { duces } \sim 21 \% \text { as much } \mathrm{O}_{3} \\
\text { as photochemistry }\end{array}$ & New Mexico & Ozonesonde & Minschwaner et al. (2008) \\
\hline $\begin{array}{l}10 \% \text { of tropospheric } \mathrm{O}_{3} \\
\text { from lightning }\end{array}$ & North America & $\begin{array}{l}\text { Ozonesonde (IONS-04) + } \\
\text { CTM model }\end{array}$ & Pfister et al. (2008) \\
\hline $\begin{array}{l}\text { Maximum } \mathrm{O}_{3} \text { loss at } 5 \mathrm{~km} \\
\text { during storm }\end{array}$ & Western Pacific & $\begin{array}{l}\text { CSRMC model for TOGA } \\
\text { COARE/CEPEX }\end{array}$ & Salzmann et al. (2008) \\
\hline
\end{tabular}

\section{Las Tablas Surface $\mathrm{O}_{3}$}

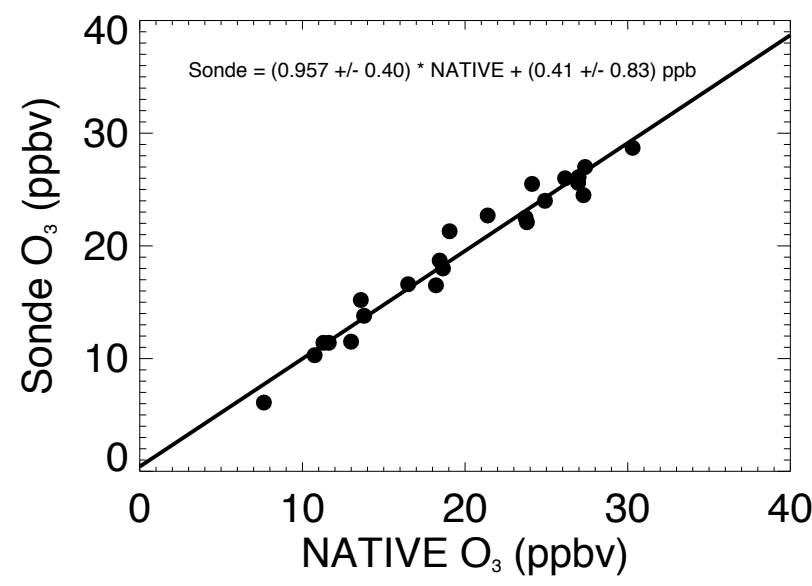

Fig. 1. A comparison between the ozonesonde readings and NATIVE surface $\mathrm{O}_{3}$ measurements at the time of launch. Agreement is good to within $\sim 5 \%$ during the TC-4 campaign.

Thompson et al., 2008). The concentration of new satellite products and aircraft instrumentation focused on convection permits us to quantify lightning, to relate flashes to improved representations in models, and to link the latter to validation of $\mathrm{NO}_{2}$ from the Ozone Measuring Instrument (OMI) aboard the NASA Aura satellite (e.g., Bucsela et al., 2010).

In addition to $\mathrm{O}_{3}$ measurements on the three TC4 aircraft, the Southern Hemisphere Additional OZonedondes (SHADOZ) (Thompson et al., 2003) Costa Rican station (Heredia, $10^{\circ} \mathrm{N}, 84^{\circ} \mathrm{W}$ ) and the TC4 site at Las Tablas, Panama $\left(7.75^{\circ} \mathrm{N}, 80.25^{\circ} \mathrm{W}\right.$; see also Thompson et al., 2010) provided $\mathrm{O}_{3}$ profiles. Virtually all the Costa Rican and Panama soundings contained free-tropospheric (FT) and lower-stratospheric wave signatures, with an incidence in the tropical tropopause layer (TTL) of $>40 \%$ (see Fig. 2a in Thompson et al., 2010). Case studies of $\mathrm{O}_{3}$ within segments affected by gravity waves demonstrated a clear link to convective activity.

The 25 Panama sondes, in a region with a high convective frequency during TC4 (Toon et al., 2010), displayed prominent wave activity associated with convection near the beginning of the mission (13-22 July 2007) and after 2 August 2007, when the TC4 aircraft coordinated sampling south of Costa Rica, in the vicinity of the Panama Bight, and as far south as the Galapagos. On 5 August, a day when all three TC4 aircraft flew over the Panama Bight, the ozonesonde launched from Las Tablas was caught in a convective system that kept it oscillating between $2.5-5.1 \mathrm{~km}$ for nearly two hours before it resumed normal ascent. Though many previous studies provided profiles before and after convection, this ozonesonde data set is unique in providing insights into changing $\mathrm{O}_{3}$ concentrations inside a dissipating tropical convective cell. Ozone increased throughout the oscillatory period, and we trace the cause to lightning-induced photochemistry. The following sections provide background with experimental details (Sect. 2), observations (Sect. 3), photochemical model results (Sect. 4), a discussion (Sect. 5), and a conclusion (Sect. 6).

\section{Data sets}

\subsection{NPOL radar}

The NASA polarimetric Doppler weather radar (NPOL) is an S-Band system operating at a frequency of $2.8 \mathrm{GHz}(10 \mathrm{~cm}$ wavelength). It has horizontal and vertical beam widths of $1.4^{\circ}$. The antenna is a flat, passive array instead of the typical parabolic dish. The design allows the system to be transported easily and allows NPOL to operate in conditions with strong winds (e.g., minimum wind loading). One of the main 
drawbacks of this design is that the signal deteriorates when the antenna is wet (Theisen et al., 2009). Therefore, the final quality-controlled dataset excludes periods when there is precipitation at the radar site.

For TC4, NPOL was deployed next to the Nittany Atmospheric Trailer and Integrated Validation Experiment (NATIVE) mobile laboratory near Las Tablas. NPOL operated almost continuously 16 July-12 August 2007, with the exception of the period 18:00 UTC 19 July-02:00 UTC 21 July. NPOL scanned with a temporal resolution of $10 \mathrm{~min}$ and spatial resolution of $200 \mathrm{~m}$ using a 12-tilt scanning strategy with elevation angles ranging from $0.7^{\circ}$ to $23.3^{\circ}$. A volume scan with a maximum range of $150 \mathrm{~km}$ preceded each long-range (to $275 \mathrm{~km}$ ) surveillance scan. NPOL-measured or derived quantities included standard radar parameters: radar reflectivity (DZ), Doppler velocity (VR), and spectral width (SW); and polarimetric parameters: differential reflectivity (ZDR), differential phase (PhiDP), specific differential phase (KDP), and cross correlation (corrHV) between horizontal and vertical polarizations. Nearly 3500 volume scans are available for studying the convective properties in and around Panama, a data set that includes a variety of interesting events, ranging from short-lived unorganized convection to long-lived mesoscale convective systems.

\subsection{World wide lightning location network}

In 2007 the World-Wide Lightning Location Network (WWLLN) (Rodger et al., 2006) consisted of approximately 25 sensors detecting lightning flashes at VLF frequencies of 3-30 kHz. WWLLN Director, Robert Holzworth, of the University of Washington provided near-real-time flash data (primarily cloud-to-ground or CG flashes) to NASA Goddard Space Flight Center (GSFC). Bucsela et al. (2010) estimated the detection efficiency of the WWLLN for total flashes (CG + intracloud or IC flashes) in the TC4 region (over open ocean near Costa Rica and Panama) through comparisons of flash rates from the Costa Rica Lightning Detection Network (CRLDN, which uses the same sensors as the United States National Lightning Detection Network, NLDN, see Cummins et al., 1998) and the Lightning Imaging Sensor (LIS) on the Tropical Rainfall Measuring Mission (TRMM) satellite for six storms. The mean detection efficiency was $0.22 \pm 0.08$, in reasonable agreement with, though somewhat higher than, the estimate of Rodger et al. (2006). There is some indication, however, that the detection efficiency is greater over the ocean than over the land in this part of the world (Lay et al., 2009).

\subsection{OMI}

OMI has been collecting data since its launch in July 2004 (Levelt et al., 2006). The instrument is a nadir-viewing spectrometer with a CCD-array having wavelength and spatial dimensions, the latter comprising 60 pixels across the flight track. The pixel area at nadir is $13 \times 24 \mathrm{~km}^{2}$, although this value increases by approximately an order of magnitude near the edges of the track. Overpass time is $\sim 13: 45$ local time in the tropics, improving the capability of OMI for observing afternoon convective events as compared with GOME and SCIAMACHY (which have morning overpass times).

Bucsela et al. (2006, 2008), Celarier et al. (2008), and Wenig et al. (2008) describe the retrieval algorithm for $\mathrm{NO}_{2}$ from OMI. It employs a spectral fitting procedure to obtain $\mathrm{NO}_{2}$ slant column densities (SCDs) from the OMI spectra. Vertical column densities (VCDs) result from dividing SCDs by air mass factors (AMFs), which are derived through radiative transfer calculations. The tropospheric component of the vertical column, including both pollution and lightning sources, is obtained by removing an unpolluted (here simply called "stratospheric") component, using a wave-2 analysis in narrow latitude bands. Because of the method used to derive it, the stratospheric VCD is contaminated by small amounts of tropospheric $\mathrm{NO}_{2}$, which we remove in the present study using output from the GMI model (Duncan et al., 2007). The corrected stratospheric VCD differs from the uncorrected value by approximately $5 \%$.

For the 5 August 2007 analysis, OMI $\mathrm{NO}_{2}$ data provide estimates of $\mathrm{LtNO}_{\mathrm{x}}$ in the region near the Gulf of Panama. Bucsela et al. (2010) provide details of the procedure, but we outline the method briefly. The first step is the calculation of the tropospheric SCD due to $\mathrm{LtNO}_{2}$, which is given by the total SCD minus the sum of the corrected stratospheric SCD and the tropospheric SCD due to sources other than lightning. This non-lightning tropospheric SCD is obtained from the OMI observations in the TC4 regions on days with a minimum of convective activity. In these calculations, all SCDs and VCDs are related through AMFs derived using radiative-transfer calculations and climatological $\mathrm{NO}_{2}$ profiles. We convert the $\mathrm{LtNO}_{2}$ slant column to a vertical column of $\mathrm{LtNO}_{\mathrm{x}}$ using a modified AMF that accounts for the vertical distribution of $\mathrm{LtNO}_{2}$ and the photolysis ratio of $\left[\mathrm{NO}_{2}\right] /\left[\mathrm{NO}_{\mathrm{x}}\right]$. The former is obtained from TC4 aircraft data, and the latter from model calculations. Beirle et al. (2009) describe a similar approach.

The uncertainties in the OMI estimate of $\mathrm{LtNO}_{\mathrm{x}}$ are dominated by uncertainties in the global stratospheric and local background concentrations. These are treated as systematic errors, as opposed to random errors. The pixel-scale errors include variations in cloud parameters, photolysis ratios and the local a priori $\mathrm{NO}_{2}$ profile, and make a negligible contribution to the total error budget. Other more significant errors include the uncertainties associated with the size of the region of interest and the number of lightning strokes contributing to the observed $\mathrm{LtNO}_{\mathrm{x}}$. As a result, the overall uncertainty in this estimate is large, though comparable to uncertainties associated with the other $\mathrm{LtNO}_{\mathrm{x}}$ estimates described below. 


\subsection{Ozonesondes}

Launched from the NATIVE facility, the electrochemical concentration cell (ECC) type (Komhyr, 1986; Komhyr et al., 1995) En-Sci $2 Z$ ozonesonde instruments with $0.5 \%$ buffered, KI cathode solution provided $\mathrm{O}_{3}$ profiles during TC4 at the Las Tablas site. The Jülich Ozone Sonde Intercomparison Experiment (JOSIE) found biases $<5 \%$, a precision of $3-5 \%$, and an accuracy of $5-10 \%$ up to $30 \mathrm{~km}$ for such sondes (Smit et al., 2007). With a typical rise rate of $\sim 5 \mathrm{~m} / \mathrm{s}$ and a measurement time constant of $\sim 25 \mathrm{~s}$, the effective vertical resolution of $\mathrm{O}_{3}$ features is $\sim 125 \mathrm{~m}$ (see also Smit et al., 2007). Most launches occurred from 12:00-15:00 local time (17:00-20:00 UTC) to coincide with the $\sim 13: 45$ local solar time overpass of NASA's Aura satellite (Schoeberl et al., 2006).

Vaisala RS80-15N radiosondes on each payload (described in Thompson et al., 2003, 2007a) measured pressure, temperature, and relative humidity (RH). Payloads also contained global positioning systems (GPS) that provided latitude, longitude, altitude, wind speed, and wind direction data. Comparisons of pressure altitude with GPS altitude provide validation of the pressure measurements. When pressure offsets occur, they are usually $<2 \mathrm{hPa}$, meaning that tropospheric $\mathrm{O}_{3}$ mixing ratios are adjusted $<\sim 2 \%(<\sim 0.2 \%$ at the surface). Post-flight processing corrects pressure errors so that at burst altitude, pressure and GPS altitudes agree to within $200 \mathrm{~m}$. For 7 of the launches during TC4, RH data above $300-500 \mathrm{hPa}$ appear unreliable. All the ozonesonde data can be found at: http://physics.valpo.edu/ozone/tc4data. html.

Although each ozonesonde is internally calibrated before each flight, Fig. 1 shows a comparison of surface $\mathrm{O}_{3}$ readings with pre-launch ozonesonde readings from the 23 flights with good $\mathrm{O}_{3}$ data during TC4. The Thermo Electron Corporation (TECO) Model 49C Ozone Analyzer, using the United States Environmental Protection Agency standard measurement technique (EQOA-0880-047) and located on the NATIVE trailer (data at: http://espoarchive.nasa.gov/archive/ $\operatorname{arcs} /$ tc $4 /$ data/native) trailer in Las Tablas, provided the preflight surface $\mathrm{O}_{3}$ data. The mean bias (sonde - NATIVE) was $-0.4 \pm 1.2 \mathrm{ppbv}$, with a root mean square difference of $1.05 \pm 0.76$ ppbv.

We compare ozonesonde columns with OMI total column ozone (Bhartia, 2007; McPeters et al., 2008) for nearby overpasses $(<50 \mathrm{~km}$ from launch site). To determine the ozone column from the ozonesonde data, we integrate ozone profiles to the burst altitude, then augment the column with either a constant mixing ratio assumption for the upper stratosphere or the Solar Backscatter Ultra-Violet (SBUV) balloon-burst climatology of McPeters et al. (1997). For the former case, the difference is $17.5 \pm 3.8 \mathrm{DU}$, while for the latter, the difference is $16.7 \pm 6.2 \mathrm{DU}$, with the sondes higher than OMI by $\sim 6 \%$. These results are consistent with the finding that the Paramaribo SHADOZ station $\left(5.8^{\circ} \mathrm{N}\right.$, $55.2^{\circ} \mathrm{W}$ ) reports columns $\sim 10 \%$ higher than OMI (Thompson et al., 2007c).

\section{Observations}

Because of the large uncertainties associated with the determination of lightning flash rates from radar and satellite data, and because of the large uncertainties in the quantities important for the calculation of $\mathrm{O}_{3}$ production from lightning flashes (e.g., ozone production efficiency, $\mathrm{NO}_{\mathrm{x}}$ per stroke of lightning, the ratio of CG to intracloud (IC) flashes), we explore this event from the perspective of many observational data sets. In Sect. 3.1, we present the NPOL observations of the lightning flashes as this cell comes across the Azuero Peninsula. In Sect. 3.2, we present observations of the same event as seen in the WWLLN data. In Sect. 3.3, we present the corresponding $\mathrm{NO}_{\mathrm{x}}$ data from the Aura OMI instrument. Finally, in Sect. 3.4, we present the in situ observations from the ozonesonde flight on 5 August 2007.

\section{$3.1 \quad$ NPOL}

NPOL observed a large convective system off the coast of Panama on 5 August 2007. The system developed during overnight hours in the Gulf of Panama and slowly propagated westward toward the Azuero Peninsula. NPOL data indicated that the precipitating area covered several hundred kilometers in the north-south direction and $\sim 100 \mathrm{~km}$ in the east-west direction, with the convective core having a mean area of $5300 \pm 2400 \mathrm{~km}^{2}$ between 09:00-17:00 UTC. The peak convection occurred $\sim 13: 11$ UTC. Figure 2 shows the reflectivity (DZ) field for 12:55-13:05 UTC. Reflectivity values ranged from about $0 \mathrm{dBZ}$ in the lighter precipitation areas to a maximum of about $55 \mathrm{dBZ}$ in the embedded convection.

Estimated wind velocities are derived from NPOL Doppler velocity field through a technique called volume velocity processing (VVP) (Boccippio, 1995). For the 5 August cell, the derived wind in the lower atmosphere was easterly at speeds on the order of $10 \mathrm{~m} / \mathrm{s}$. With each time step, however, moderate directional shear appeared, with directions fluctuating from southeast to northeast (in agreement with the ozonesonde observations, see Sect. 3.4 below).

This convective system generated a significant number of lightning strikes. Figure 2 indicates the location of flashes between 12:55 and 13:05 UTC detected by the WWLLN (see Sect. 3.3 below) are well correlated with areas active convection indicated by the NPOL data. We use radar reflectivity data from NPOL to estimate lightning flash rates using the parameterization of Futyan and DelGenio (2007), which predicts the total flash rate $\mathrm{IC}+\mathrm{CG}=F$ (flashes $/ \min / 300 \mathrm{~km}^{2}$ ) to be

$$
F=0.208\left(H_{17 \mathrm{~dB}}-H_{0}{ }^{\circ} \mathrm{C}\right)^{1.8}
$$


Table 2. Flashes detected by the World Wide Lightning Location Network (WWLLN Flashes), estimated flashes using the WWLLN detected flashes and the network flash detection efficiency (WWLLN Flashes*), and flashes calculated from radar heights estimated by the NPOL radar (uncertainties in parenthesis) near the Gulf of Panama on 5 August 2007. WWLLN Flashes 2 refer to flashes detected in the region upwind of the DC-8 spiral on 5 August 2007. See text for details of each.

\begin{tabular}{lrrrrr}
\hline Hours (UTC) & $\begin{array}{r}\text { WWLLN } \\
\text { Flashes }\end{array}$ & $\begin{array}{r}\text { WWLLN } \\
\text { Flashes* }\end{array}$ & $\begin{array}{r}\text { NPOL } \\
\text { Flashes }\end{array}$ & $\begin{array}{r}\text { WWLLN } \\
\text { Flashes 2 }\end{array}$ & $\begin{array}{r}\text { WWLLN } \\
\text { Flashes 2* }\end{array}$ \\
\hline 00:00-08:00 & 9 & $41(15)$ & 0 & 103 & $470(170)$ \\
08:00-09:00 & 4 & $18.2(6.6)$ & 0 & 51 & $230(84)$ \\
09:00-10:00 & 36 & $163(60)$ & $9(10)$ & 26 & $118(43)$ \\
10:00-11:00 & 61 & $277(101)$ & 0 & 9 & $41(15)$ \\
11:00-12:00 & 34 & $155(56)$ & $44(72)$ & 13 & $59(21)$ \\
12:00-13:00 & 174 & $791(288)$ & $240(61)$ & 13 & $59(21)$ \\
13:00-14:00 & 160 & $727(264)$ & $450(240)$ & 0 & 0 \\
14:00-15:00 & 92 & $418(152)$ & $670(110)$ & 0 & 0 \\
15:00-16:00 & 6 & $27(10)$ & $600(100)$ & 0 & 0 \\
16:00-17:00 & 0 & $0(0)$ & $240(78)$ & 0 & 0 \\
17:00-18:00 & 1 & $4.5(1.7)$ & $11(13)$ & 0 & 0 \\
18:00-19:00 & 2 & $9.1(3.3)$ & $1.7(2.1)$ & 5 & $22.7(8.3)$ \\
19:00-20:00 & 9 & $41(15)$ & $4.3(6.3)$ & 0 & 0 \\
20:00-24:00 & 150 & $682(248)$ & $108(63)$ & 34 & $155(56)$ \\
\hline Total 09:00-17:00 & $\mathbf{5 6 3}$ & $\mathbf{2 5 6 0 ( 4 4 0 )}$ & $\mathbf{2 3 0 0 ( 3 0 0 )}$ & $\mathbf{6 1}$ & $\mathbf{2 7 7 ( 5 5 )}$ \\
TOTAL & $\mathbf{7 3 8}$ & $\mathbf{3 4 0 0 ( 5 0 0 )}$ & $\mathbf{2 4 0 0 ( 3 1 0 )}$ & $\mathbf{2 5 4}$ & $\mathbf{1 1 6 0}(\mathbf{2 1 0})$ \\
\hline
\end{tabular}

where $H_{17 \mathrm{~dB}}$ is the storm-averaged height $(\mathrm{km})$ of the $17 \mathrm{~dB}$ radar-return signal and $H_{0}{ }^{\circ} \mathrm{C}$ is the height of the $0^{\circ} \mathrm{C}$ (freezing) level. From the ozonesonde data, we find $H_{0}{ }^{\circ} \mathrm{C}$ is $\sim 4.5$ $\mathrm{km}$. From the radar data, we determine hourly averages of $H_{17 \mathrm{~dB}}$ and the area of the storm. Table 2 shows the resulting hourly flash estimates for 5 August. During the period from the genesis of the cell to the final ascent of the balloon (09:00-17:00 UTC), this parameterization predicts a total of $2300 \pm 300$ flashes.

We can use the NPOL-derived flash data to estimate the photochemical lightning production of $\mathrm{O}_{3}\left(\mathrm{LtpcO}_{3}\right)$ from LtNO. Estimates of LtNO vary widely (Pickering et al., 2009; Huntrieser et al., 2008; Koike et al., 2007; Hudman et al. 2007; Drapcho et al., 1983) from a low of 43 moles/flash (Skamarock et al., 2003) to a high of 1100 moles/flash (Price et al., 1997, Winterath et al., 1999). Pierce (1970) and Prentice and Mackerras (1977) estimate the ratio of IC flashes to $\mathrm{CG}$ flashes for $\sim 8^{\circ} \mathrm{N}$ to be 6.5-8.0. Estimates of the NO production efficiency of IC-to-CG flashes varies from 0.1 (Price et al., 1997) to 1.4 (Fehr et al., 2004). Lin et al. (1988) estimate the production of 30 moles of $\mathrm{O}_{3}$ per mole of $\mathrm{NO}_{\mathrm{x}}$, (i.e., an ozone production efficiency, OPE, of 30) in box model studies of surface $\mathrm{O}_{3}$ pollution while more recent studies find OPE in the range 4-12. For example, Shon et al. (2008) found an OPE of 4.5 for air downwind of an industrial complex air in Mexico and 8.5 for free tropospheric marine air; Wood et al. (2009) found an OPE of $\sim 7$ over the course of a day at a mountain observatory near Mexico City; and Zaveri et al. (2003) used aircraft and surface observations during the
Southern Oxidant Study, finding OPEs increased with plume age from $\sim 2-5.6$. (Note: for our calculations of $\mathrm{LtpcO}_{3}$, we scale the OPE to account for the limited 2-h period between the first and final ascent and assume that enough sunlight was available on the edge of the cell to drive the photochemistry).

Using a Monte Carlo approach to combine the various parameters cited above, we estimate $\mathrm{LtpcO}_{3}$ of $(4.2 \pm 4.0) \times 10^{6}$ moles from this cell. The large uncertainty in this estimate owes to the remaining high uncertainty in all of the quantities that go into the calculation. Recalculating with values that we feel are most representative of the conditions for this cell (tropical, marine, etc.: $\mathrm{OPE}=2$; moles $\mathrm{NO} /$ flash $=227$ as suggested by Bucsela et al. (2010); IC:CG NO production efficiency $=1$, we determine our best estimate of $\mathrm{LtpcO}_{3}$ to be $1.0 \times 10^{6}$ moles using on the NPOLbased lightning flash rates.

If we assume $\mathrm{O}_{3}$ is produced directly from coronal discharges, estimated from the number of lightning strikes $\left(\mathrm{LtdO}_{3}\right)$ at $300-3000 \mathrm{moles} / \mathrm{flash}$, as in Minschwaner et al. (2008), we predict $(3.7 \pm 1.8) \times 10^{6}$ moles of $\mathrm{O}_{3}$ for the flashes between 09:00-17:00 UTC. Since the ozonesonde observations suggest that the $\mathrm{O}_{3}$ production was ongoing during at least the 108 -min period after launch, only the $\mathrm{LtdO}_{3}$ after launch is relevant. Therefore, if we restrict our calculation to the flashes during the two-hour period after launch (see Table 2), we find possible $(1.39 \pm 0.70) \times 10^{6}$ moles of $\mathrm{LtdO}_{3}$. 


\subsection{WWLLN}

WWLLN reported frequent lightning in association with the convective cell over the Gulf of Panama on 5 August. Table 2 summarizes the number of flashes per hour detected in the box defined by the latitude range $7.25^{\circ}-8.75^{\circ} \mathrm{N}$ and longitude range $78.75^{\circ}-81.25^{\circ} \mathrm{W}$, the region of the Gulf of Panama through which the convective cell passed. Figure 2 shows good correlation between the locations of the lightning flashes and the areas of active convective seen by the NPOL radar for 12:55-13:05 UTC. Notably, the CRLDN observed few if any lightning flashes over the Gulf of Panama on this day. Given the spatial distribution of lightning flashes observed by the CRLDN (not shown), it appears that the Gulf of Panama fell in a shadow of the network.

Using the WWLLN flash data between 09:00-17:00 UTC, we can estimate the associated total $\mathrm{LtpcO}_{3}$, as we did for the NPOL data above with one further modification. Bucsela et al. (2010) estimated lightning detection efficiency of $0.22 \pm 0.08$ for the WWLLN in the TC4 region. Accounting for this factor, we find 2560 \pm 930 flashes between 09:0017:00 UTC, in reasonable agreement with the NPOL estimate of $2300 \pm 300$ flashes. (Hour-by-hour estimates of the efficiency corrected WWLLN flashes can also be found in Table 2.)

Using a Monte Carlo approach to combine the factors in Sect. 3.1 above with the WWLLN flash estimate, we find $(3.3 \pm 4.5) \times 10^{6}$ moles of $\mathrm{LtpcO}_{3}$, with our best estimate of $1.2 \times 10^{6}$ moles (using values associated with conditions more likely to be found in the present case, as we did for the NPOL calculation above), consistent with the NPOL estimate.

If we assume direct production of $\mathrm{O}_{3}$ via coronal discharges at 300-3000 moles/flash, as in Minschwaner et al. (2008), and use the WWLLN efficiency corrected lightning strikes, we project $(4.2 \pm 2.2) \times 10^{6}$ moles of $\mathrm{LtdO}_{3}$ for the flashes between 09:00-17:00 UTC. Although the cloud parameterization used to estimate lightning frequency from the NPOL data (see Table 2) suggests lightning continued during the sonde oscillation period (15:00-17:00 UTC), the WWLLN suggests little-to-no lightning during this period. This mechanism, therefore, is not indicated by the WWLLN data for post-launch $\mathrm{O}_{3}$ production.

\subsection{OMI NO}

It is difficult to discern the $\mathrm{LtNO}_{2}$ signal from an examination of Level 2 OMI tropospheric $\mathrm{NO}_{2}$ and cloud fraction data products that result from the standard retrieval conducted at NASA Goddard Space Flight Center (Bucsela et al., 2006), in part because the Level 2 data have not been cloud screened. With reprocessing that includes removing an estimate of background $\mathrm{NO}_{2}$ and applying an air mass factor more appropriate for convective outflow (Bucsela et al., 2010), the $\mathrm{LtNO}_{2}$ becomes more evident. Fig. 3 shows

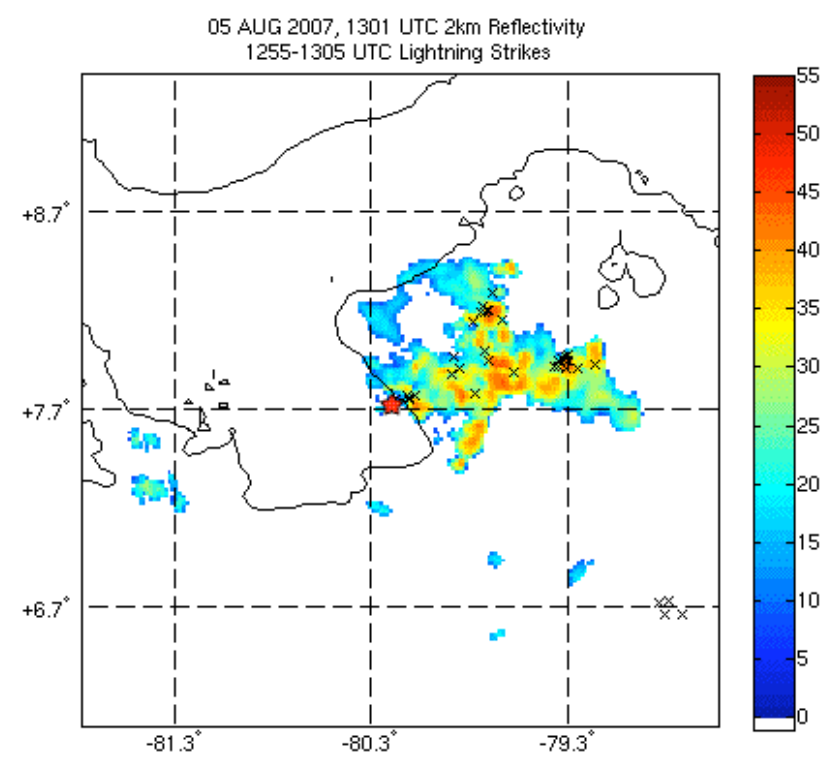

Fig. 2. Low-level (0.7 elevation) PPI images of convection observed east of NPOL at 13:11 UTC 5 August 2007. The color scale has units of radar reflectivity (dBZ). Each " $\mathrm{X}$ " marks the location of a detected WWLLN lightning strike. The red star marks the location of Las Tablas.

a map of the $\mathrm{LtNO}_{\mathrm{x}}$ field near the Gulf of Panama on $5 \mathrm{Au}-$ gust 2007 after reprocessing (considering the $\mathrm{NO}_{\mathrm{x}}$ to $\mathrm{NO}_{2}$ ratio at cloud-outflow levels). The boxed area $\left(\sim 54000 \mathrm{~km}^{2}\right)$ contains $1020 \pm 860 \mathrm{kmol} \mathrm{LtNO}_{\mathrm{x}}$, which would result in (1.2-8.9) $\times 10^{6}$ moles of $\mathrm{O}_{3}$ (depending on the OPE selected). If we scale this estimate to the size of the core of the convective cell observed on the NPOL radar (average area of $\sim 5300 \mathrm{~km}^{2}$ from 09:00-17:00 UTC), the estimated $\mathrm{LtpcO}_{3}$ becomes $(1.2-8.6) \times 10^{5}$ moles, with a best estimate of $(2.0 \pm 1.7) \times 10^{5}$ moles, whereas if we scale it to match the area of flashes detected by the WWLLN $\left(\sim 46000 \mathrm{~km}^{2}\right)$, we find a range of (1.0-7.6) $\times 10^{6}$ moles with a best estimate of $(1.7 \pm 1.5) \times 10^{6}$ moles. Scaling by the larger area of the WWLLN estimate results in the best agreement with the NPOL and WWLLN $\mathrm{LtpcO}_{3}$ estimates detailed above. While the uncertainties are large, the values appear to be above background.

\subsection{Ozone profiles}

The ozonesonde launch on 5 August occurred at 15:05 UTC to coincide with the scheduled arrival of the NASA aircraft in the Panama area. At the time of launch, rain fell as part of the convective cell that had just moved ashore from the east, although ground observers reported no visible lightning. The surface temperature was $\sim 24^{\circ} \mathrm{C}$ with $\mathrm{RH}$ of $96 \%$ and a surface pressure of $\sim 1003 \mathrm{hPa}$. 


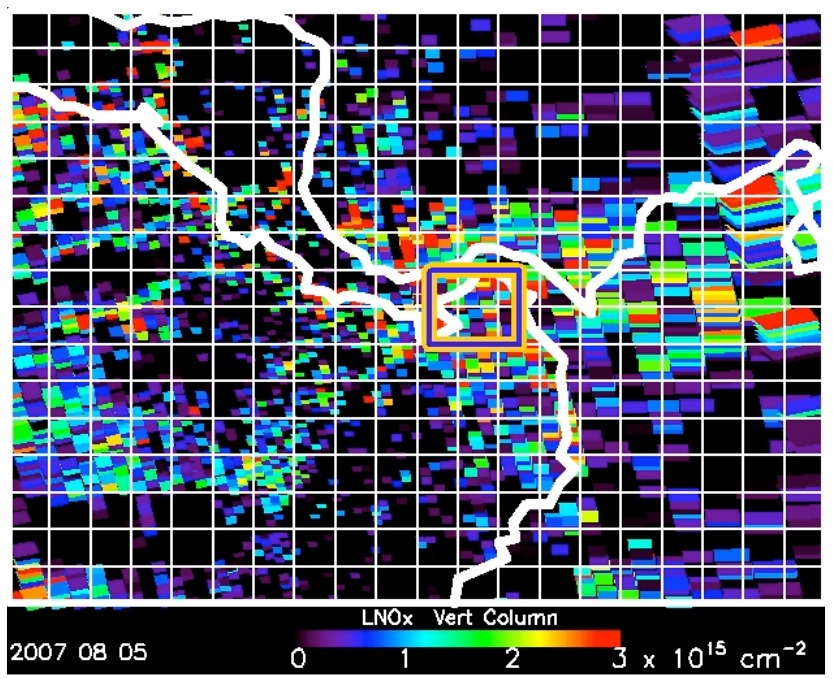

Fig. 3. Gridded $\left(1^{\circ} \times 1^{\circ}\right)$ OMI lightning $\mathrm{NO}_{\mathrm{x}}$ in the Panama area on 5 August 2007. The larger region was used for the first estimate, while the smaller boxed region in the Gulf of Panama was used for the second estimate (see text).

About 20 min into the flight, the balloon reached $5.1 \mathrm{~km}$ and began to descend. About 15 min later, it began to ascend again. Between launch and 17:00 UTC, the balloon oscillated up and down through the air mass between $\sim 2.5$ and $\sim 5.1 \mathrm{~km}$ five times, as shown in Fig. 4. (Note: each ascent is color-coded so subsequent figures can be analyzed more easily.) Although the detailed explanation for this behavior is beyond the scope of this paper (see Morris, 2011), it appears to be a combination of downdrafts on the southern side of the westward-moving convective cell (based on NPOL radar data) and changing mass due to repeated condensation/evaporation of water and freezing/melting of ice on the surface of the balloon.

Figure 5 shows the $\mathrm{O}_{3}$ concentrations measured on each ascent. Over the $\sim 2 \mathrm{~h}$ between the original ascent and the final ascent, $\mathrm{O}_{3}$ in the layer between $\sim 2.5$ and $\sim 5.1 \mathrm{~km}$ increased 4-12 ppbv, with a mean increase of $7.9 \pm 4.7 \mathrm{ppbv}$. Integrating the change in $\mathrm{O}_{3}$ between the first and last profiles from $2.55-5.11 \mathrm{~km}$ (the range of the oscillation), and assuming uniform production across the area of the storm $\left(5300 \pm 2400 \mathrm{~km}^{2}\right.$ as indicated by the NPOL data from 09:00-17:00 UTC) in this layer, we find a potential of $\sim 3.0 \times 10^{6}$ moles of $\mathrm{O}_{3}$ (with $\sim 50 \%$ uncertainty) created as part of this cell, a number that agrees within roughly a factor of two with the best estimates from the lightning data (see Sects. 3.1 and 3.2) and the OMI data (see Sect. 3.3 above). We note that the estimates from the lightning data and from OMI represent the total $\mathrm{LtpcO}_{3}$ throughout the cloud, whereas our sonde estimate is based only on the enhancements in the $2.5-5.1 \mathrm{~km}$ layer.

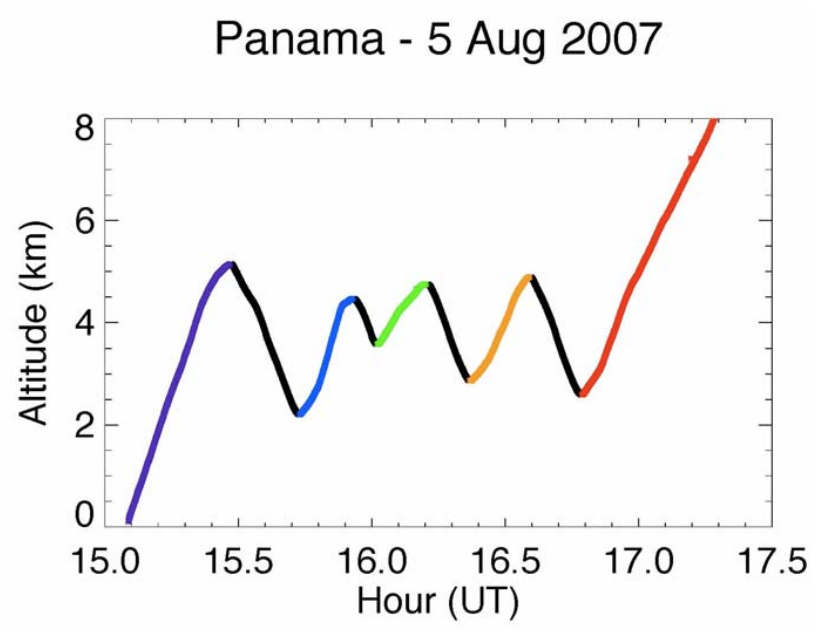

Fig. 4. The altitude vs. time of the ozonesonde flight on 5 August 2007 from Las Tablas, Panama shows the balloon oscillating 5 times between $\sim 2.5$ and $\sim 5.1 \mathrm{~km}$. The color coding of each ascent will be used in successive plots to identify changes with time of other measured parameters.

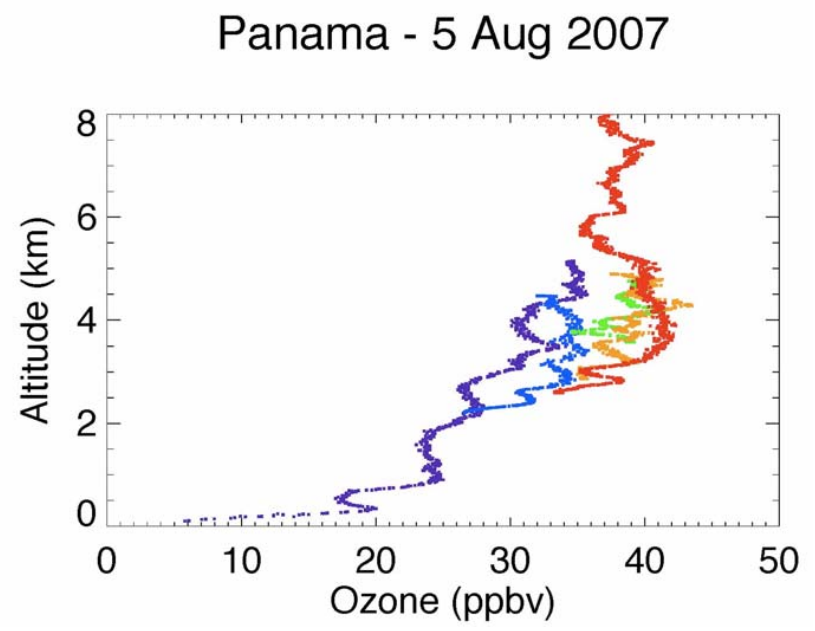

Fig. 5. Ozone vs. altitude on the ascents as the balloon oscillated on the 5 August 2007 flight, with color coding to match the ascents identified in Fig. 4.

Geostationary Operational Environment Satellite (GOES) data indicate cloud top temperatures consistent with heights of $14-15 \mathrm{~km}$ as the cell developed over the Gulf of Panama, descending to $11-12 \mathrm{~km}$ as the cell dissipated when moving ashore. Moderate-resolution Imaging Spectrometer (MODIS) data for this cell suggest the cloud tops reach 10$12 \mathrm{~km}$. Both satellite data sets indicate the clouds reached altitudes far above the top of the layer in which the balloon oscillated. To get a better estimate of $\mathrm{LtO}_{3}$ throughout the cloud and estimate changes in $\mathrm{O}_{3}$ above $5.1 \mathrm{~km}$, therefore, we use the $\mathrm{O}_{3}$ data from the DC- 8 flight around 
the Gulf of Panama on 5 August. The mean DC-8 in situ $\mathrm{O}_{3}$ profiles before 17:17 UTC and after 17:17 UTC can be seen in Fig. 6. Figure 7 shows the locations of the "before"/"after" data points, with the former marked by green stars and the latter by green diamonds. If we integrate the difference between the final ozonesonde ascent profile and the mean aircraft profiles (before and after 17:17 UTC) from $2.5-12.0 \mathrm{~km}$, we find $4.2 \times 10^{6}$ and $3.1 \times 10^{6}$ moles, respectively. Using the combination of the in situ DC-8 measurements and the ozonesonde data, we find that 70-97\% of the ozone molecules were created in the layer in which the balloon oscillated (i.e., $2.5-5.1 \mathrm{~km}$ ).

The DC-8 differential absorption lidar (DIAL) observations, shown as the small colored dots in Fig. 6, provide evidence for higher $\mathrm{O}_{3}$ downwind of convection as compared to observations upwind in clear-sky regions around the Gulf of Panama. The colors are coded to match the locations of these observations along the flight track shown in Fig. 7. Integrating the upwind-downwind differences from $1.6-8.5 \mathrm{~km}$, we find an increase (post minus pre) of $1.3 \times 10^{7}$ moles of $\mathrm{O}_{3}$, with roughly two-thirds of this change occurring between $1.6-6.0 \mathrm{~km}$.

Returning to the ozonesonde observations, the total change in $\mathrm{O}_{3}$ as observed by the balloon is given by

$\frac{d\left[\mathrm{O}_{3}\right]}{d t}=\frac{\delta\left[\mathrm{O}_{3}\right]}{\delta t}+\boldsymbol{v} \cdot \nabla\left[\mathrm{O}_{3}\right]$

where the first term represents in situ photochemical production (loss) and the second term represents changes due to advection. If the balloon had remained in the same air parcel within the cloud or if no wind sheer existed over the vertical range of oscillation, we could assume that the observations were Lagrangian, meaning the advection term would vanish. Figure 8 shows the wind speeds and directions on each ascent of the balloon as determined from on board GPS data. Because of the vertical wind shear within the cell (seen by NPOL and in the balloon data), the advection term (resulting from the difference between the trajectories of the balloon and the air parcels in which observations were taken) may be non-negligible, so we investigate further below.

Table 3 shows the calculated differences between the GPSrecorded balloon positions and the estimated subsequent positions of the air masses sampled on the first ascent at three levels $(2.75,3.75$, and $4.75 \pm 0.15 \mathrm{~km})$. To make these estimates, we calculated trajectories based upon GPS wind speed and direction vertically averaged in each of the three layers on successive ascents. We multiplied the resulting $u$ (east-west wind) and $v$ (north-south wind) values by the time difference between successive ascents to get longitude and latitude displacements. Since the balloon did not oscillate through all three layers each time, the table contains some "No data" entries. These calculations suggest separations of $15-30 \mathrm{~km}$ between the originally- and finally-sampled air masses, providing a constraint on the horizontal scale of potential $\mathrm{O}_{3}$ gradients.

\section{Panama - 5 Aug 2007}

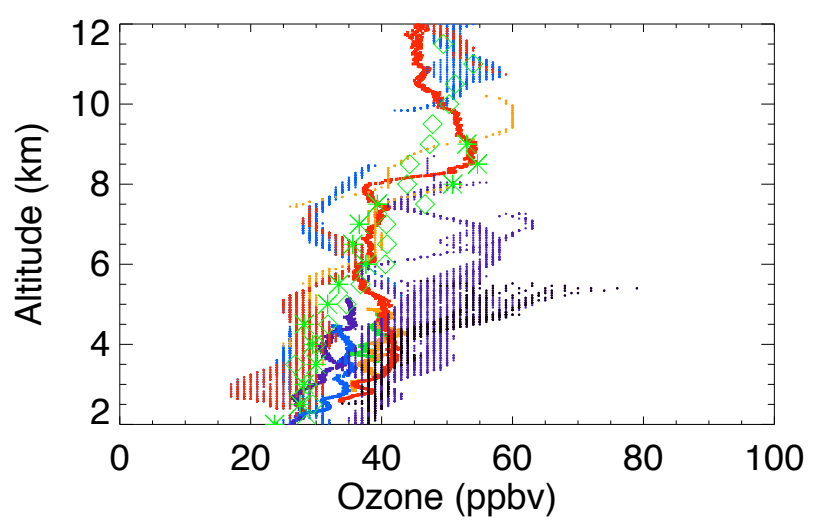

Fig. 6. Ozone profiles on 5 August 2007 in the Gulf of Panama region from sonde (thick colors), DC-8 DIAL (colored dots), and mean DC-8 in situ (green diamonds before 17:17 UTC and green stars after 17:17 UTC). See text for details.

\section{DC-8 Flight Path - 5 August 2007}

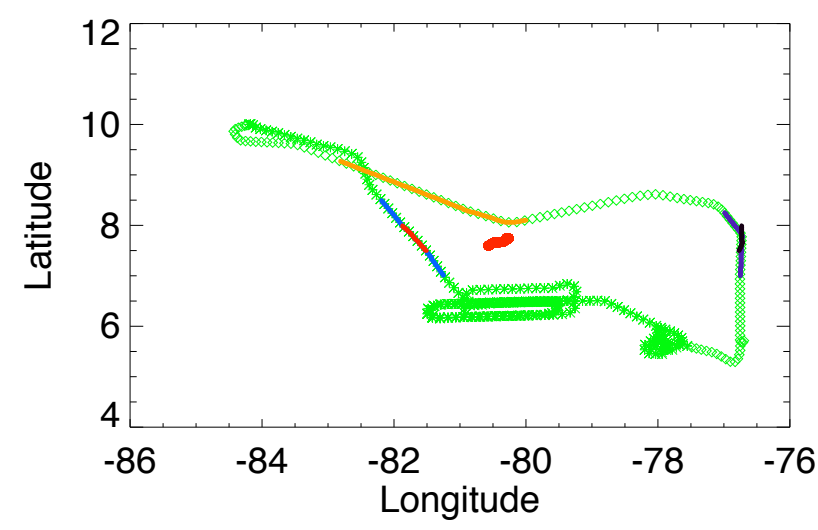

Fig. 7. DC-8 flight path with green stars marking the flight path prior to $17: 17$ UTC and the green diamonds marking the flight path after 17:17 UTC. The colored dots superimposed on the flight path correspond to DC-8 DIAL measurement locations, with the colorcoding to match the profiles seen in Fig. 6.

Figure 9 shows the change in $\mathrm{O}_{3}$ with time as a function of altitude, calculated as the difference between the $\mathrm{O}_{3}$ at a given altitude as measured on each ascent with that measured on the first ascent. Changes of 3-10 ppbv/hr are derived, with the highest rates at $2.5-3.0 \mathrm{~km}$ between the first and second ascents, and at 3.5-4.5 km between the first and third ascents. We note from Table 3 that for the former case, the balloon is located about $5 \mathrm{~km}$ upwind from the original air mass, somewhat farther from the center of the storm as it comes ashore. For the latter case, the balloon is located about $13 \mathrm{~km}$ downwind of the original air mass, closer to the center of the cell. 


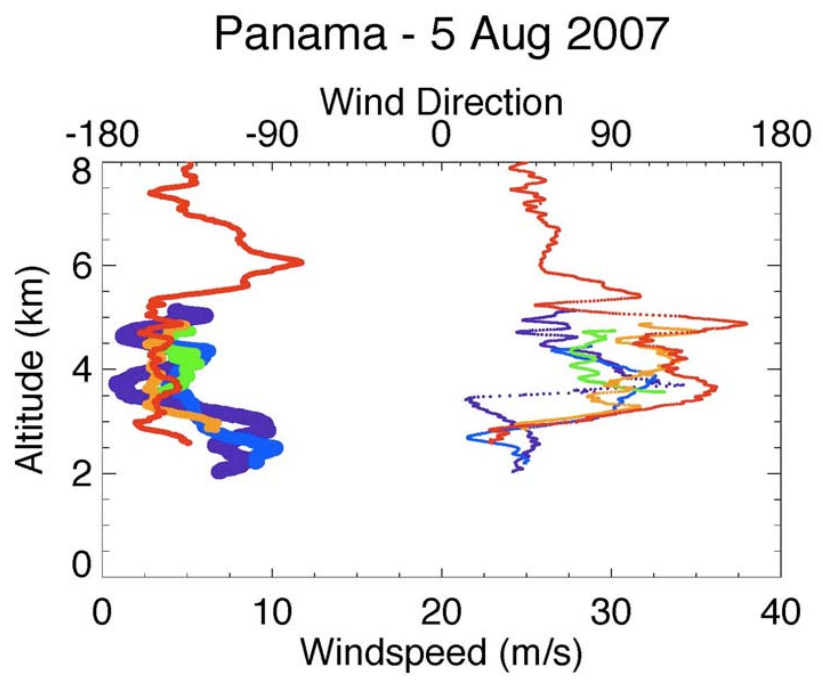

Fig. 8. Wind speed (thick) and direction (thin) as determined from the ozonesonde GPS data. The balloon moved through a region of vertical shear, resulting in the separation of the balloon trajectory from the trajectories of the air masses the sonde sampled. See text and Table 3 for further details.

\section{Panama - 5 Aug 2007}

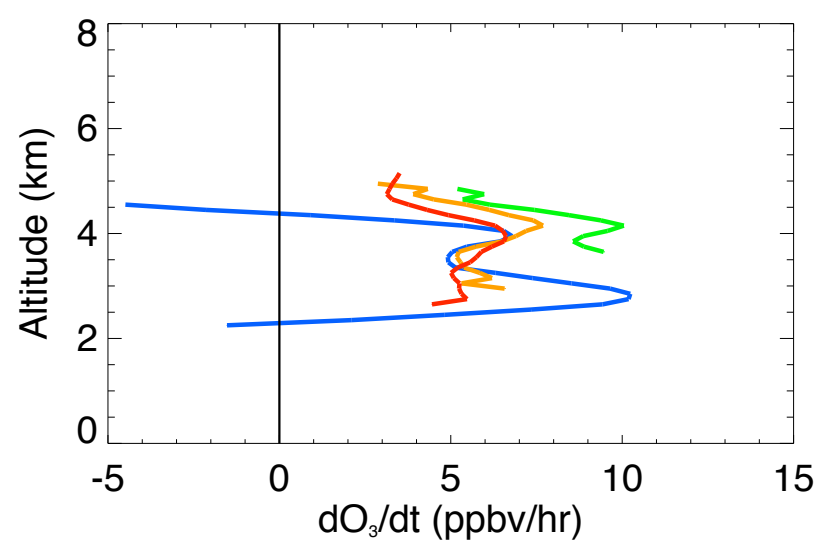

Fig. 9. Calculated $\mathrm{dO}_{3} / \mathrm{dt}$ vs. altitude for the ascents of the flight on the 5 August 2007 flight, with color coding to match the ascents identified in Fig. 4. See text for details.

Since both profiles suggest somewhat large $\mathrm{O}_{3}$ changes with time, with one being upwind and the other being downwind of the original air masses, it seems likely that the advection term over these spatial scales is relatively small.

One last component of the advection term to investigate is the vertical term. While some of the change in $\mathrm{O}_{3}$ is due to descent, most of the change appears to be due to other factors. First, the original ascending profile in Fig. 5 (purple) joins with near perfect continuity the final ascending profile between 5 and $5.5 \mathrm{~km}$, suggesting the $\mathrm{O}_{3}$ enhancements

\section{August - Las Tablas, PANAMA}

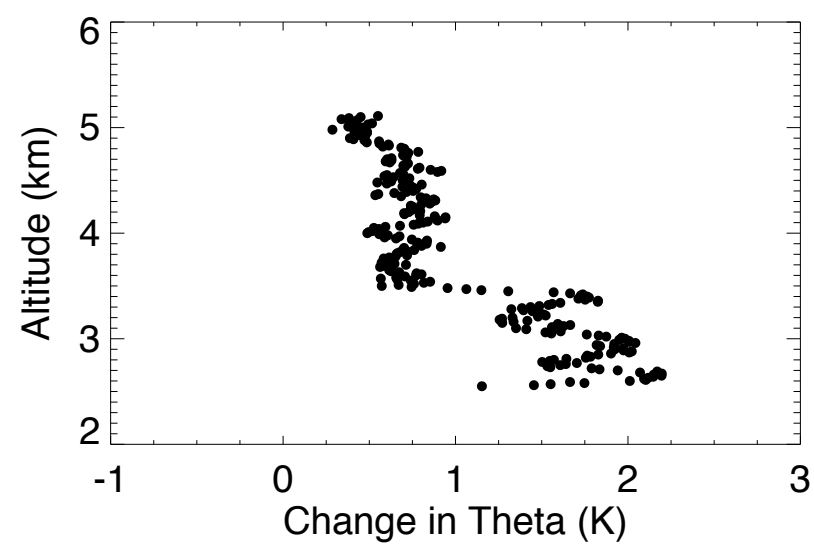

Fig. 10. The change in potential temperature from the first to the last ascent vs. altitude for the flight of 5 August 2007.

are not due to air descending from above $5.5 \mathrm{~km}$. Second, Fig. 10 shows the change in potential temperature (theta) between the first and final ascent as a function of altitude between $2.55-5.11 \mathrm{~km}$, with warming between 2.55 and $\sim 3.40 \mathrm{~km}$ of $1.25-2.25 \mathrm{~K}$, and between $3.4-5.11 \mathrm{~km}$ of $0.25-$ $1.0 \mathrm{~K}$. If we assume that the change in theta in the lower layer is due solely to descent, the air found in the 2.55$3.40 \mathrm{~km}$ layer on the last pass was originally between 3.09 $3.55 \mathrm{~km}$. The mean $\mathrm{O}_{3}$ in this layer (defined by theta) on the first pass was $32.1 \pm 1.3$ ppbv while on the last pass, it was $37.9 \pm 2.2 \mathrm{ppbv}$, a difference of $5.8 \pm 2.6 \mathrm{ppbv}$. If we assume no descent at all, the mean $\mathrm{O}_{3}$ in this layer (defined by altitude) was $29.5 \pm 1.9 \mathrm{ppbv}$ on the first pass, a difference of $8.4 \pm 2.9 \mathrm{ppbv}$. Thus, we attribute $2.6 \pm 3.9 \mathrm{ppbv}(\sim 31 \%)$ of the change to descent of air between the first and last ascents, with air descending at an average rate of $6.2 \mathrm{~cm} / \mathrm{s}$. Reducing the observed change in $\mathrm{O}_{3}$ of 4-12 ppbv over $\sim 108 \mathrm{~min}$ (the time between the first and final ascent) by the $30 \%$ due to descent, the balloon data project $1.5-4.6 \mathrm{ppbv} / \mathrm{hr}$ change in $\mathrm{O}_{3}$.

Figure 11 shows $\mathrm{O}_{3}$ as a function of theta rather than height for the first and last ascents. Integrating the change in $\mathrm{O}_{3}$ as a function of theta between $311.75-320.00 \mathrm{~K}$, and assuming the cell size as before, we find an increase of $2.5 \times 10^{6}$ moles of $\mathrm{O}_{3}$, agreeing within roughly a factor of two with the estimates from the lightning data detailed above.

To establish characteristics of the large scale flow, we calculated back trajectories from $2.75-4.75 \mathrm{~km}$ using both the Hysplit model (Draxler and Rolph, 2010) using Global Data Assimilation System (GDAS) meteorological fields (horizontal resolution of $1^{\circ}$ latitude $\times 1^{\circ}$ longitude) and a kinematic version of the NASA Goddard Space Flight Center trajectory model (GTM, Schoeberl and Sparling, 1995) using National Centers for Environmental Predication (NCEP) reanalysis meteorological fields (horizontal resolution of $1^{\circ}$ 
Table 3. Balloon trajectory and estimated air mass trajectories at three different altitudes within the $2.5-5.1 \mathrm{~km}$ layer in which the balloon oscillated. "No data" are reported when the balloon did not oscillate through the level of the air mass trajectory calculation. The "Direction" column indicates the compass heading from the balloon location to the estimated air mass location. Color-coding matches that for the balloon data shown in Figs. 4, 5, 8, 9, and 11. See text for details.

\begin{tabular}{lrrrrrrr}
\hline $\begin{array}{l}\text { Trajectory } \\
\text { Altitude }(\mathrm{km})\end{array}$ & $\begin{array}{r}\text { Time from } \\
\text { launch }(\mathrm{s})\end{array}$ & $\begin{array}{r}\text { Balloon } \\
\text { lat }(\mathrm{deg})\end{array}$ & $\begin{array}{r}\text { Air mass } \\
\text { lat }(\mathrm{deg})\end{array}$ & $\begin{array}{r}\text { Balloon } \\
\text { lon }(\mathrm{deg})\end{array}$ & $\begin{array}{r}\text { Air mass } \\
\text { lon }(\mathrm{deg})\end{array}$ & $\begin{array}{r}\text { Separation } \\
(\mathrm{km})\end{array}$ & $\begin{array}{r}\text { Direction } \\
(\mathrm{deg})\end{array}$ \\
\hline \multirow{3}{*}{$2.75 \mathrm{~km}$} & 614 & 7.734 & 7.734 & -80.269 & -80.269 & 0.000 & 0 \\
& 2555 & 7.677 & 7.661 & -80.337 & -80.382 & 5.246 & 250 \\
& no data & no data & no data & no data & no data & no data & no data \\
& 4629 & 7.660 & 7.597 & -80.418 & -80.492 & 10.816 & 230 \\
& 6208 & 7.654 & 7.550 & -80.463 & -80.551 & 15.103 & 220 \\
\hline \multirow{3}{*}{$3.75 \mathrm{~km}$} & 859 & 7.724 & 7.724 & -80.277 & -80.277 & 0.000 & 0 \\
& 2766 & 7.674 & 7.683 & -80.346 & -80.262 & 9.320 & 84 \\
& 3459 & 7.671 & 7.657 & -80.374 & -80.260 & 12.672 & 97 \\
& 5010 & 7.654 & 7.605 & -80.431 & -80.261 & 19.494 & 106 \\
$4.75 \mathrm{~km}$ & 6535 & 7.655 & 7.565 & -80.469 & -80.235 & 27.614 & 111 \\
\hline & 1134 & 7.722 & 7.722 & -80.284 & -80.284 & 0.000 & 0 \\
& no data & no data & no data & no data & no data & no data & no data \\
& 3956 & 7.667 & 7.635 & -80.393 & -80.307 & 10.116 & 111 \\
& 5335 & 7.658 & 7.582 & -80.440 & -80.300 & 17.591 & 118 \\
& 6806 & 7.659 & 7.544 & -80.476 & -80.269 & 26.130 & 119 \\
\hline
\end{tabular}

latitude $\times 1^{\circ}$ longitude and a 6 -h time resolution). The results from both models suggest that air masses between 2.75 and $4.75 \mathrm{~km}$ moved across the Gulf of Panama from the ENE to Las Tablas over the $8 \mathrm{~h}$ prior to the balloon observation, consistent with the motion of the cell seen in the NPOL radar data. The trajectory data, therefore, suggest that the air mass was not a mixture of air from vastly different source regions.

\section{Photochemical modeling}

In a effort to simulate the $\mathrm{O}_{3}$ changes observed by the 5 August 2007 ozonesonde, we ran a zero-dimensional photochemical box model with Regional Atmospheric Chemical Mechanism (RACM, Stockwell et al., 1997) to calculate the concentrations of radicals and other reactive intermediates. Rate coefficients of the reactions in RACM were updated by Jet Propulsion Laboratory (JPL) data evaluation (Sander et al., 2006) as applicable. The model was constrained by a set of 1-min resolution merged observations of temperature, pressure, $\mathrm{H}_{2} \mathrm{O}, \mathrm{O}_{3}, \mathrm{CO}, \mathrm{NO}, \mathrm{NO}_{2}, \mathrm{HNO}_{3}$, NMHC, ethanol, acetone, MACR, MVK, and benzene from NASA DC-8 aircraft at 16:45-17:00 UTC on 5 August 2007. During this time period, the aircraft was spiraling downward from 5.2 to $0.3 \mathrm{~km}$ near $5.7^{\circ} \mathrm{N}$ and $78.0^{\circ} \mathrm{W}$, in a clear-sky region to the southeast of the active region of convection in which the balloon measurements occurred. Unmeasured photolysis frequencies were calculated for clear sky condition from the Tropospheric Ultraviolet and Visible (TUV) model (http://www.acd.ucar.edu/TUV) or based on the solar zenith angle equations in Jenkin et al. (1997) and then scaled by the photolysis frequency of $\mathrm{NO}_{2}$ calculated from the NCAR CCD Actinic Flux Spectroradiometers (CAFS) measurements made on the NASA WB-57 aircraft that flew in the vicinity of active convection around the same time as the DC-8. The model was run with the FACSIMILE software (MCPA Software Ltd.) for sufficient time to reach instantaneous steady state of the intermediates.

The instantaneous net $\mathrm{O}_{3}$ production, $P_{\text {net }}\left(\mathrm{O}_{3}\right)$, can be calculated by

$$
\begin{aligned}
& P_{\text {net }}\left(\mathrm{O}_{3}\right)=\mathrm{P}\left(\mathrm{O}_{3}\right)-L\left(\mathrm{O}_{3}\right) \\
& =k_{\mathrm{NO}+\mathrm{HO}_{2}}[\mathrm{NO}]\left[\mathrm{HO}_{2}\right]+\Sigma k_{\mathrm{NO}+\mathrm{RO}_{2} i}[\mathrm{NO}]\left[\mathrm{RO}_{2}\right] \\
& -k_{\mathrm{OH}+\mathrm{NO}_{2}+\mathrm{M}}[\mathrm{M}]\left[\mathrm{NO}_{2}\right][\mathrm{OH}]-k_{\mathrm{O} 1 \mathrm{D}+\mathrm{H}_{2} \mathrm{O}} \\
& {\left[\mathrm{O}^{1} \mathrm{D}\right]\left[\mathrm{H}_{2} \mathrm{O}\right]} \\
& -k_{\mathrm{HO}_{2}+\mathrm{O}_{3}}\left[\mathrm{HO}_{2}\right]\left[\mathrm{O}_{3}\right]-k_{\mathrm{OH}+\mathrm{O}_{3}}[\mathrm{OH}]\left[\mathrm{O}_{3}\right] \text {, }
\end{aligned}
$$

where the various $k$ 's represent the rate coefficients of the corresponding reactions associated with the production and loss of $\mathrm{O}_{3}$. The resulting calculated net ozone production as a function of altitude is shown in Fig. 12a, with a mean value of $0.84 \mathrm{ppbv} / \mathrm{hr}$ between $2-5 \mathrm{~km}$. Because this aircraft spiral occurred in a region with much less convective activity than the cell in which the ozonesonde made its measurements, we performed four additional model runs with $\mathrm{NO}_{\mathrm{x}}$ concentrations $150 \%, 200 \%, 300 \%$ and $500 \%$ of those detected in 


\section{August - Las Tablas, PANAMA}

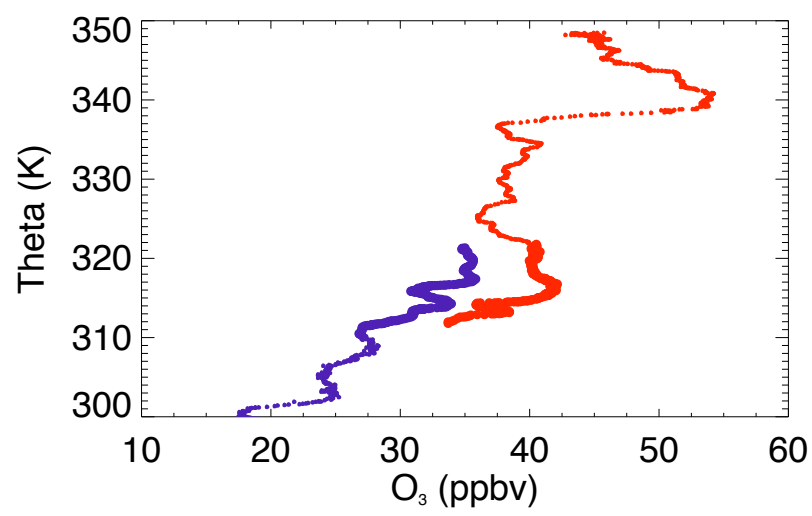

Fig. 11. Ozone vs. potential temperature for the first and last ascents of the flight of 5 August 2007 shows that the changes cannot be due to descent of the air mass alone.

this spiral (Fig. 12a). The runs resulted in $2-5 \mathrm{~km}$ averaged $P_{\text {net }}\left(\mathrm{O}_{3}\right)$ of $1.5,2.2,3.3$, and $5.3 \mathrm{ppbv} / \mathrm{hr}$, respectively.

Table 2 summarizes the WWLLN flash detection for $5 \mathrm{Au}$ gust in a box defined by $5.0-6.5^{\circ} \mathrm{N}, 75.5-78.5^{\circ} \mathrm{W}$, a box of roughly the same area as used for the analysis of the convective cell in the Gulf of Panama discussed above. This box is located upwind of the area of the DC- 8 spiral on 5 August. Hysplit trajectory calculations (not shown) suggest that air sampled by the DC-8 in its spiral would have been located in this box earlier in the day. The WWLLN data indicate that the air mass sampled during the DC- 8 spiral saw only $\sim 10 \%$ as much lightning from 09:00-17:00 UTC and only $\sim 34 \%$ as much lightning for the entire day as the area near the convective cell. Increases of $\mathrm{NO}_{\mathrm{x}}$ by a factor or 2-3 for use in modeling $\mathrm{LtpcO}_{3}$, therefore, are reasonable, if not conservative.

Figure $12 \mathrm{~b}$ examines the sensitivity of the calculated net ozone production rates on the photochemical rate constants. DeCaria et al. (2005) suggest a linear scaling of the clear sky photolysis rate constants using adjustment factors ranging from 0.1 at the base to 2.0 at the top of a very dense cloud, and from 0.4 at the base to 1.7 at the top of a dense cloud. Because we do not know the precise structure of the cloud in which the balloon oscillated, we perform a sensitivity study, scaling the photolysis rates by the amounts suggested by DeCaria et al. (2005) and using the $200 \% \mathrm{NO}_{\mathrm{x}}$ case described above. The average net ozone production for the $0.1,0.4,1.7$, and 2.0 cases are $0.83,1.5,2.6$, and $2.7 \mathrm{ppbv} / \mathrm{hr}$ respectively.

The Cloud Physics Lidar (CPL, McGill et al., 2004) and Cloud Radar System (CRS, Hlavka et al., 2010 ${ }^{1}$ ) data from the DC-8 flight on 5 August (shown in Fig. 10 of Thompson

\footnotetext{
${ }^{1}$ Hlavka, D., Tian, L., Hart, W., Li, L., McGill, M., and Heymsfield, G.: Vertical cloud climatology during TC4 derived from highaltitude aircraft merged lidar and radar, unpublished manuscript, 2010.
}

(a)

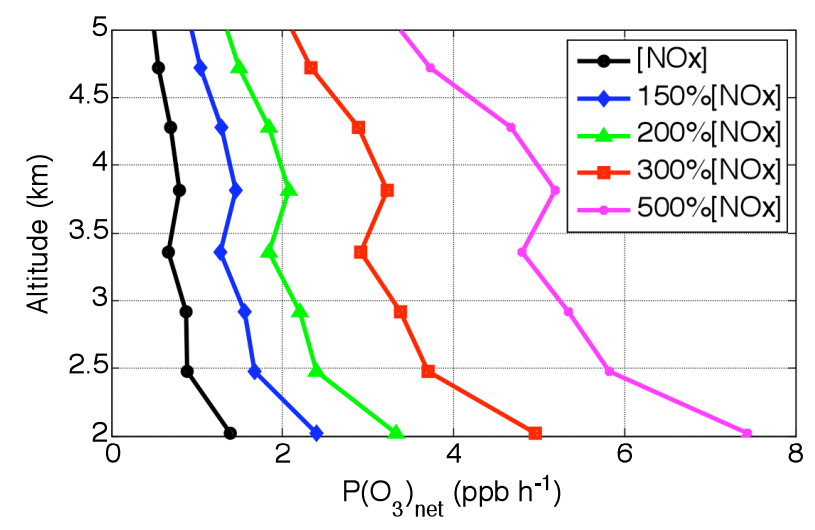

(b)

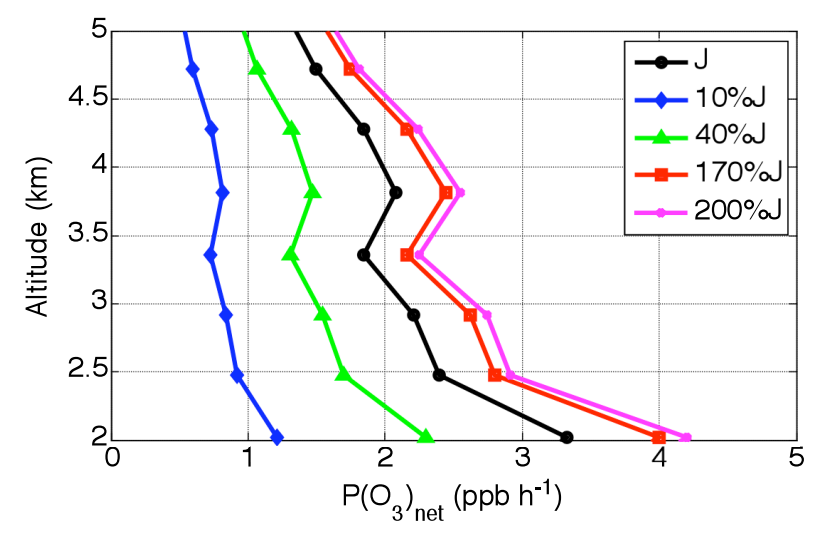

Fig. 12. Calculated ozone net production $P_{\text {net }}\left(\mathrm{O}_{3}\right)$ within the altitude of $2-5 \mathrm{~km}$ based on the modeling results from the aircraft data at UTC 16:45-17:00 on 5 August 2007 with initial and controlled (a) $\mathrm{NO}_{\mathrm{x}}$ concentrations and (b) photolysis rates ( $J$ values) with $200 \%\left[\mathrm{NO}_{\mathrm{x}}\right]$ case.

et al., 2010) suggest some structure topping out in the 4$6 \mathrm{~km}$ altitude range, near the top of the range of the balloon oscillation. The production rates in the cloud sampled on 5 August, therefore, should move from the 0.1 or 0.4 scaled curves in Fig. 12b near $2.5 \mathrm{~km}$ toward the 1.0 to 2.0 scaled curves near $5.0 \mathrm{~km}$, resulting in estimated production rates of $1.0-1.7 \mathrm{ppbv} / \mathrm{hr}$ near $2.5 \mathrm{~km}$ to $1.3-1.6 \mathrm{ppb} / \mathrm{hr}$ near $5.0 \mathrm{~km}$. Thus, the photochemical model results are consistent with $\sim 1.0-2.5 \mathrm{ppbv} / \mathrm{hr}$ in the $2-5 \mathrm{~km}$ altitude range sampled by the oscillating balloon. (We note that by using the $500 \% \mathrm{NO}_{\mathrm{x}}$ case for this sensitivity analysis, we find $\sim 2.1-4.7 \mathrm{ppbv} / \mathrm{hr}$ at the cloud base and $\sim 3.5-4.5 \mathrm{ppbv} / \mathrm{hr}$ near $5.0 \mathrm{~km}$, results that are quite consistent with the rates calculated from the balloon data above).

To support the use of enhanced $\mathrm{NO}_{\mathrm{x}}$ in the photochemical model, we examine aircraft NO data, gathered using a chemilumenescence technique (Fontjin et al., 1970; Pearson and Stedman, 1980), and $\mathrm{NO}_{2}$ data, gathered using the thermal dissociation - laser induced fluorescence technique (Thornton et al., 2000), from all DC-8 flights during TC-4. 
These data are shown in Fig. 13 and only measurements recorded at least $10 \mathrm{~min}$. after take-off, at most $10 \mathrm{~min}$. before landing, and at least $50 \mathrm{~km}$ away from the airport in Alujuela, Costa Rica $\left(10.0^{\circ} \mathrm{N}, 84.2^{\circ} \mathrm{W}\right)$ are included in the plot. Relatively high values of $\mathrm{NO}_{\mathrm{x}}$ can be found throughout the troposphere. Tables 4 and 5 summarize all occasions when the $\mathrm{NO}$ and $\mathrm{NO}_{2}$ concentrations exceeded $1.0 \mathrm{ppbv}$. We note two of these occasions in particular: (1) on 21 July 2007, a peak of 1.0-3.1 ppbv of NO is observed over the Carribean Sea between 3.7-6.2 km; (2) on 29 July 2007, a peak of 1.0-1.5 ppbv of NO between $6.3-7.4 \mathrm{~km}$ and a peak of 1.0 $1.8 \mathrm{ppbv}$ of $\mathrm{NO}_{2}$ between $5.5-7.4 \mathrm{~km}$ is observed over the Pacific Ocean. Observation 1 occurred as the aircraft was descending after passing through an area of fresh convection, as indicated by the GOES IR data (anlger.larc.nasa.gov/tc4) for 21 July 2007. Observation 2 occurred just off the west coast of Costa Rica immediately following take-off. The aircraft encountered a region of fresh convection, as indicated by the GOES IR data for 29 July 2007. These two examples from the TC4 aircraft data support the possibility that $\mathrm{NO}_{\mathrm{x}}$ production associated with fresh convection can be observed in the mid-troposphere.

\section{Discussion}

This work has presented a unique ozonesonde profile over Las Tablas, Panama on 5 August 2007. The balloon initially ascended on the southern side of a dissipating convective cell as it came ashore from the east. Between 09:00 and 17:00 UTC, WWLLN data indicate 563 flashes $(\sim 2600$ flashes accounting for the lightning detection efficiency of this network) in and around the Gulf of Panama, while estimates of lightning flash rates using NPOL radar height data result in $\sim 2300$ flashes associated with this cell. The ozonesonde oscillated 5 times between $\sim 2.5$ and $\sim 5.1 \mathrm{~km}$ for $\sim 108 \mathrm{~min}$ and measured $4-12 \mathrm{ppbv} \mathrm{O}_{3}$ increases. Examination of the meteorological data gathered on the sonde flight suggests that $\sim 30 \%$ of the increase may be due to descent of higher $\mathrm{O}_{3}$ from above. As a result, we calculate $\mathrm{LtO}_{3}$ from the balloon measurements of $1.5-4.6 \mathrm{ppbv} / \mathrm{hr}$. Using data gathered on DC-8 flight in the Gulf of Panama region on 5 August 2007, we initialized a run of the RACM to evaluate $\mathrm{LtpcO}_{3}$ from the background conditions. Although the aircraft samples used to initialize the RACM run came from a region with only $10-34 \%$ as many lightning flashes, the base run showed a $\mathrm{LtpcO}_{3}$ of $1.5 \mathrm{ppbv} / \mathrm{hr}$ between $2-$ $5 \mathrm{~km}$. Increasing $\mathrm{NO}_{\mathrm{x}}$ by a factor of 2-3 and compensating for changes in photolysis rates due to cloud cover, as suggested by DeCaria et al. (2005), led to net $\mathrm{LtpcO}_{3}$ of 1.0$2.5 \mathrm{ppbv} / \mathrm{hr}$ (increasing $\mathrm{NO}_{\mathrm{x}}$ by a factor of 5 yields net ozone production rates of $2.1-4.7 \mathrm{ppbv} / \mathrm{hr}$ ). The RACM model results, therefore, indicate that most of the $\mathrm{LtpcO}_{3}$ observed by the ozonesonde can result from known photochemistry.
A number of previous studies have suggested that strong $\mathrm{O}_{3}$ increases are seen at higher altitudes downwind of convective activity (see Table 1 for a summary of previous findings). For example, DeCaria et al. (2005) found $\mathrm{O}_{3}$ production of $10 \mathrm{ppbv} /$ day near $9 \mathrm{~km}$, and Pickering et al. (1996) and Thompson et al. (1997) found 7-8 ppbv/day in the 8-12 km.

Other studies suggest $\mathrm{O}_{3}$ losses due to titration by $\mathrm{NO}$ near $5 \mathrm{~km}$ in association with convective cells, including 6-8 ppbv losses found in Ridley et al. (2006), 9 ppbv losses during a convective event in Europe at $5.5 \mathrm{~km}$ reported by Ott et al. (2007), and maximum $\mathrm{O}_{3}$ losses at $5 \mathrm{~km}$ during a storm in the tropical Pacific reported by Salzmann et al. (2008).

But numerous previous studies also have reported large increases in $\mathrm{O}_{3}$ in the lower troposphere. Dickerson et al. (1987) found a peak in $\mathrm{O}_{3}$ at $5 \mathrm{~km}$ in association with convective activity, while Pickering et al. (1990) suggest the highest potential $\mathrm{O}_{3}$ production of 7-17 ppbv/day below $5 \mathrm{~km}$. Viewed in this context, our ozonesonde observations provide evidence for this layer of enhanced $\mathrm{O}_{3}$ in the lower troposphere.

The rapid increase of $\mathrm{O}_{3}$ seen in our sonde data may suggest that much of the $\mathrm{O}_{3}$ production occurs soon after daylight returns to the air mass affected by the cell rather than over the course of a day, a hypothesis consistent with the laboratory work of Franzblau (1991, see his Fig. 2 which shows rapid recovery of $\mathrm{O}_{3}$ in $<10 \mathrm{~min}$. when a UV lamp illuminates a controlled chamber after electrical discharges result in loss of $\mathrm{O}_{3}$ through reactions with $\mathrm{LtNO}_{\mathrm{x}}$ ). Although our balloon payload contained no instruments with which direct measurements of radiation could be made, the meteorological observations from the ozonesonde flight are consistent with increasing radiation at $2.5-5.1 \mathrm{~km}$ over the time of the oscillations. In particular, the sonde reported higher temperatures (by $0.92 \pm 0.46^{\circ} \mathrm{C}$ ) and lower humidity (by $9.2 \pm 4.8 \%$ ) on the final ascent as compared to the initial ascent between 2.6 and $5.1 \mathrm{~km}$, both of which are consistent with increased sunlight. This explanation also is consistent with Ott et al. (2007), who reported 9 ppbv losses of $\mathrm{O}_{3}$ during a storm with large amounts of $\mathrm{LtNO}_{\mathrm{x}}$, but $5 \mathrm{ppbv/day}$ production of $\mathrm{O}_{3}$ downwind at $5.5 \mathrm{~km}$.

Significant changes in the lower free tropospheric $\mathrm{O}_{3}$ associated with convective activity are consistent with the lower portion of the $\mathrm{C}$-shaped $\mathrm{LtNO}_{\mathrm{x}}$ profile of Pickering et al. (1998), which shows $15.9 \%$ of the LtNOx below $5 \mathrm{~km}$, and the updated profiles of Ott et al. (2010), which shows $14.7 \%$ of $\mathrm{LtNO}_{\mathrm{x}}$ below $5 \mathrm{~km}$. While the ICARTT data shown in Hudman et al. (2007) do not indicate a significant enhancement of $\mathrm{NO}_{\mathrm{x}}$ in the $2-6 \mathrm{~km}$ altitude range, the DC- 8 did not sample in this altitude range near convective activity; nevertheless the higher variability in $\mathrm{NO}_{\mathrm{x}}$ and corresponding lack of a similar increase in variability in the $\mathrm{CO}$ data at $3.5 \mathrm{~km}$ (see their Fig. 3) may be explained by lower tropospheric $\mathrm{LtNO}_{\mathrm{x}}$. As pointed out by Ridley et al. (2004), for cases in which CG flashes occur outside of the convective core or in regions of the convective cell influenced by downdrafts, 
Table 4. Measurements of NO $>1 \mathrm{ppbv},>50 \mathrm{~km}$ away from Alajuela, Costa Rica airport $\left(10.0^{\circ} \mathrm{N}, 84.2^{\circ} \mathrm{W}\right)$ from DC-8 flights during TC4. Enhanced $\mathrm{NO}<8 \mathrm{~km}$ are highlighted orange over Columbia, blue over open water, and yellow over the west coast of Costa Rica.

\begin{tabular}{lrrrr}
\hline Date & Altitude $(\mathrm{km})$ & Latitudes & Longitudes & NO (ppbv) \\
\hline 21 Jul 2007 & 10.7 & $4.3^{\circ} \mathrm{N}$ & $76.1^{\circ} \mathrm{W}$ & $1.0-1.1$ \\
\hline 21 Jul 2007 & $4.6-6.4$ & $4.0^{\circ}-4.4^{\circ} \mathrm{N}$ & $73.4^{\circ}-73.9^{\circ} \mathrm{W}$ & $1.0-1.8$ \\
21 Jul 2007 & $0.5-0.6$ & $4.2^{\circ} \mathrm{N}$ & $73.6^{\circ} \mathrm{W}$ & $1.3-2.5$ \\
\hline 21 Jul 2007 & 10.9 & $10.3^{\circ}-11.5^{\circ} \mathrm{N}$ & $75.6^{\circ}-77.9^{\circ} \mathrm{W}$ & $1.0-2.1$ \\
\hline 21 Jul 2007 & $3.7-6.2$ & $12.0^{\circ}-12.2^{\circ} \mathrm{N}$ & $80.2^{\circ}-80.3^{\circ} \mathrm{W}$ & $1.0-3.1$ \\
\hline 21 Jul 2007 & $2.9-5.8$ & $9.5^{\circ}-9.9^{\circ} \mathrm{N}$ & $84.3^{\circ}-84.6^{\circ} \mathrm{W}$ & $1.0-4.8$ \\
22 Jul 2007 & $11.0-12.2$ & $12.2^{\circ}-15.1^{\circ} \mathrm{N}$ & $78.4^{\circ}-79.1^{\circ} \mathrm{W}$ & $1.0-1.6$ \\
24 Jul 2007 & 10.6 & $5.3^{\circ} \mathrm{N}$ & $85.1^{\circ}-85.4^{\circ} \mathrm{W}$ & $1.0-1.3$ \\
22 Jul 2007 & $7.9-8.6$ & $8.4^{\circ}-8.6^{\circ} \mathrm{N}$ & $84.6^{\circ} \mathrm{W}$ & $1.4-3.6$ \\
28 Jul 2007 & $11.6-11.9$ & $13.6^{\circ}-14.6^{\circ} \mathrm{N}$ & $81.8^{\circ}-82.8^{\circ} \mathrm{W}$ & $1.0-2.2$ \\
28 Jul 2007 & $10.4-11.9$ & $8.7^{\circ}-9.7^{\circ} \mathrm{N}$ & $86.4^{\circ}-87.3^{\circ} \mathrm{W}$ & $1.0-2.0$ \\
\hline 29 Jul 2007 & $6.3-7.4$ & $8.8^{\circ}-9.2^{\circ} \mathrm{N}$ & $84.4^{\circ} \mathrm{W}$ & $1.0-1.5$ \\
29 Jul 2007 & $9.7-10.7$ & $1.2^{\circ}-7.5^{\circ} \mathrm{N}$ & $84.3^{\circ}-84.9^{\circ} \mathrm{W}$ & $1.0-2.2$ \\
29 Jul 2007 & $11.0-12.1$ & $6.5^{\circ}-9.9^{\circ} \mathrm{N}$ & $78.8^{\circ}-81.8^{\circ} \mathrm{W}$ & $1.0-2.1$ \\
3 Aug 2007 & $9.4-12.2$ & $7.7^{\circ}-9.3^{\circ} \mathrm{N}$ & $80.1^{\circ}-83.8^{\circ} \mathrm{W}$ & $1.0-2.3$ \\
5 Aug 2007 & $11.0-11.5$ & $6.0^{\circ}-8.9^{\circ} \mathrm{N}$ & $78.0^{\circ}-82.0^{\circ} \mathrm{W}$ & $1.0-1.3$ \\
6 Aug 2007 & $9.8-10.3$ & $2.3^{\circ}-6.1^{\circ} \mathrm{N}$ & $88.8^{\circ}-92.2^{\circ} \mathrm{W}$ & $1.2-2.2$ \\
8 Aug 2007 & $9.4-12.2$ & $5.8^{\circ}-8.9^{\circ} \mathrm{N}$ & $81.2^{\circ}-84.2^{\circ} \mathrm{W}$ & $1.0-2.2$ \\
10 Aug 2007 & $8.9-11.0$ & $11.8^{\circ}-16.3^{\circ} \mathrm{N}$ & $85.5^{\circ}-87.5^{\circ} \mathrm{W}$ & $1.0-1.8$ \\
\hline
\end{tabular}
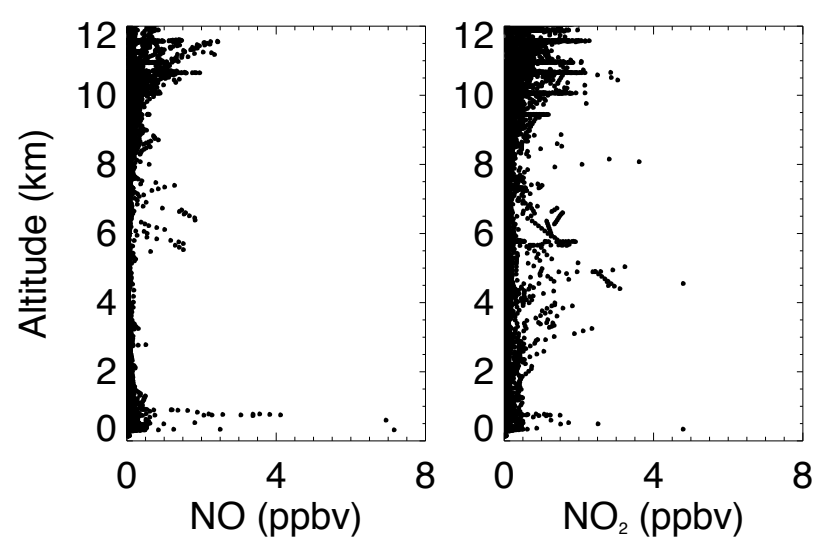

Fig. 13. $\mathrm{NO}$ and $\mathrm{NO}_{2}$ measurements aboard the DC-8 aircraft during TC4. All measurements taken at least $10 \mathrm{~min}$ after take-off and $10 \mathrm{~min}$ before landing at a distance of $>50 \mathrm{~km}$ from the airport in Alajuela, Costa Rica airport $\left(10.0^{\circ} \mathrm{N}, 84.2^{\circ} \mathrm{W}\right)$ are shown.

enhancements of $\mathrm{LtNO}_{\mathrm{x}}$ are likely in the lower troposphere. In fact, the DC-8 data from at least two TC4 flights near active convection found $\mathrm{NO}_{\mathrm{x}}$ enhancements in the $3.5-7.5 \mathrm{~km}$ altitude region (21 and 29 July 2007, see Tables 4 and 5). Given the location of our ozonesonde profile on the southern edge of the dissipating convective cell, either of these possibilities may explain our sonde observation. Furthermore, the changes observed by the ozonesonde during the $108 \mathrm{~min}$ of its oscillation do not represent typical variability within this layer during a single day of the TC4 mission. To assess this variability, we examine the differences between ascending and descending ozonesonde measurements from $2.5-5.1 \mathrm{~km}$, measurements that are typically separated by $\sim 2 \mathrm{~h}$ in time and $\sim 100 \mathrm{~km}$. Using all flights with both ascending and descending data within this layer taken during TC4, we find that only $\sim 30 \%$ of data in this altitude range showed absolute changes $>4$ ppbv, only $\sim 5 \%$ of data in this altitude range showed absolute changes of $>12$ ppbv; only $\sim 13 \%$ of all data showed differences $>+4$ ppbv and $<1 \%$ showed changes $>+12$ ppbv. We also note that for the 5 August flight, $100 \%$ of the data from $2.6-5.1 \mathrm{~km}$ show $\mathrm{O}_{3}$ increases. Of the 14 flights for which we have descending data at more than $50 \%$ of the levels from 2-6 km, only 3 flights (other than the 5 August flight) had at least $80 \%$ of the levels in this altitude range with increased $\mathrm{O}_{3}$, with mean increases of $5.8 \pm 3.4 \mathrm{ppbv}, 3.7 \pm 2.6 \mathrm{ppbv}$, and $2.8 \pm 1.3 \mathrm{ppbv}$. These differences are less than those seen on the 5 August, which showed a mean increase of $7.8 \pm 2.2 \mathrm{ppbv}$. Thus, the $5 \mathrm{Au}-$ gust flight appears unique among all of our TC4 ozonesonde flights in terms of ozone changes observed over $\sim 2 \mathrm{~h}$ between 2 and $6 \mathrm{~km}$.

Wind profiles from the sonde and NPOL data indicate some vertical divergence within the layer of observed $\mathrm{O}_{3}$ changes. Subsequent trajectory calculations suggest the possible separation of the originally sampled air mass from that sampled on the final ascent by $15-30 \mathrm{~km}$ over the $\sim 108 \mathrm{~min}$. Thus, horizontal $\mathrm{O}_{3}$ gradients with a scale $<30 \mathrm{~km}$ and/or in situ photochemistry may explain some of the sondeobserved changes in $\mathrm{O}_{3}$. In the former case, the original air mass at $2.75 \mathrm{~km}$ ends up $\sim 15 \mathrm{~km}$ to the southwest of balloon 
Table 5. Measurements of $\mathrm{NO}_{2}>1 \mathrm{ppbv},>50 \mathrm{~km}$ away from Alajuela, Costa Rica airport $\left(10.0^{\circ} \mathrm{N}, 84.2^{\circ} \mathrm{W}\right)$ from DC-8 flights during TC4. Enhanced $\mathrm{NO}<8 \mathrm{~km}$ are highlighted orange over Columbia and blue over open water.

\begin{tabular}{lrrrr}
\hline Date & Altitude $(\mathrm{km})$ & Latitudes & Longitudes & $\mathrm{NO}_{2}(\mathrm{ppbv})$ \\
\hline 21 Jul 2007 & $10.4-10.7$ & $2.5-6.3^{\circ} \mathrm{N}$ & $76.1-77.5^{\circ} \mathrm{W}$ & $1.0-1.3$ \\
21 Jul 2007 & $0.5-0.6$ & $4.2^{\circ} \mathrm{N}$ & $73.6^{\circ} \mathrm{W}$ & $1.0-1.8$ \\
22 Jul 2007 & 0.3 & 8.3 & $84.8^{\circ} \mathrm{W}$ & $7.2-14.2$ \\
\hline 22 Jul 2007 & $10.5-11.6$ & $6.1^{\circ}-7.9^{\circ} \mathrm{N}$ & $80.7^{\circ}-84.2^{\circ} \mathrm{W}$ & $1.0-2.3$ \\
22 Jul 2007 & 12.2 & $11.3^{\circ}-12.6^{\circ} \mathrm{N}$ & $78.2^{\circ}-84.2^{\circ} \mathrm{W}$ & $1.0-1.3$ \\
\hline 24 Jul 2007 & 0.3 & $5.4^{\circ} \mathrm{N}$ & $85.8^{\circ} \mathrm{W}$ & $1.3-2.5$ \\
29 Jul 2007 & $5.5-7.4$ & $8.8^{\circ}-9.4^{\circ} \mathrm{N}$ & $84.4^{\circ} \mathrm{W}$ & $1.0-1.8$ \\
\hline
\end{tabular}

trajectory (see Table 3), so the balloon ends up falling backward relative to the westward moving center of the cell and the original air mass. As $\mathrm{O}_{3}$ increases, the dynamical explanation would require higher $\mathrm{O}_{3}$ concentrations outside of the cell in less dense clouds in which photochemical $\mathrm{O}_{3}$ production may take place and in which loss of $\mathrm{O}_{3}$ through reactions with NO from lightning may not have occurred. At 3.75 and $4.75 \mathrm{~km}$, however, the trajectories suggest the original air mass ends up 25-30 km southeast of the balloon trajectory, resulting in the balloon sampling air closer to the center of the cell. After the last oscillation, the balloon position is on the southeastern edge of the storm, whereas for the first oscillation it was just west of the center of the cell. At these higher altitudes, it would seem that the balloon is sampling air more representative of the cell core, which suggests $\mathrm{O}_{3}$ levels within the cell have actually increased. Thus, we argue that the changes observed by the ozonesonde cannot be explained entirely by entrainment into or detrainment from the convective cell.

Assuming the sonde-observed changes in $\mathrm{O}_{3}$ are representative of the entire cell $\left(\sim 5300 \mathrm{~km}^{2}\right)$, an increase of $\sim 3.0 \times 10^{6}$ moles of $\mathrm{O}_{3}$ between $2.5-5.1 \mathrm{~km}$ may be associated with this storm. Based on comparisons of the ozonesonde profile with in situ profiles from the DC- 8 , the total increase in $\mathrm{O}_{3}$ from $2.5-12 \mathrm{~km}$ may have been (3.1$4.2) \times 10^{6}$ moles, a result that suggests $70-97 \%$ of the increase occurred in the $2.5-5 \mathrm{~km}$ layer.

Lidar data from the DC- 8 also indicated large $\mathrm{O}_{3}$ differences between the profiles taken downwind and upwind of the cell: the lidar data report $\sim 1.3 \times 10^{7}$ more moles of $\mathrm{O}_{3}$ after the passing of the cell between $1.6-8.5 \mathrm{~km}$, with $6.3 \times 10^{6}$ of those between $2.5-5.1 \mathrm{~km}$ and $8.6 \times 10^{6}$ between $1.6-6.0 \mathrm{~km}$. These differences could be due to spatial gradients in $\mathrm{O}_{3}$, but the horizontal scale over which those gradients appear is $\sim 550 \mathrm{~km}$, much greater than the $\sim 30 \mathrm{~km}$ horizontal distance (measured relative to the convective cell motion) over which the ozonesonde detected similarly large changes.

Furthermore, if we reduce our ozonesonde $\mathrm{LtpcO}_{3}$ estimate by $30 \%$ to account for changes in $\mathrm{O}_{3}$ that can be attributed to descending air with higher $\mathrm{O}_{3}$, we find $\sim(2.1-2.5) \times 10^{6}$ moles of $\mathrm{O}_{3}$ created, an estimate which agrees within a factor of two of our best estimates from the WWLLN data $\left(\sim 1.2 \times 10^{6}\right.$ moles $)$, from the NPOL data $\left(\sim 1.0 \times 10^{6}\right.$ moles $)$, and from the $\mathrm{OMI} \mathrm{LtNO}_{2}$ data $\left(\sim 1.7 \times 10^{6}\right.$ moles, provided we scale by the larger area considered with the WWLLN data rather than the convective core area indicated by the NPOL data), although the estimates from the WWLLN and NPOL data carry large uncertainties due to the large uncertainties associated with the parameters included in the photochemical production calculations.

Finally, we estimate direct production of $(1.39 \pm 0.70) \times 10^{6}$ moles of $\mathrm{O}_{3}$ from coronal discharges (during the two-hour period after launch) from the lightning data derived from NPOL. We note, however, that this scenario is not supported by the WWLLN data, in which little to no lightning is detected after the ozonesonde launch.

\section{Conclusions}

While the precise mechanism responsible for the $\mathrm{O}_{3}$ changes observed by the oscillating ozonesonde remains uncertain, several possibilities are suggested by the data. We list them here in order, with the one we find most likely first. (1) If lightning and photochemistry are responsible for the changes in $\mathrm{O}_{3}$, our ozonesonde observations are consistent with the hypothesis that shortly after the lightning strikes, NO reacts with $\mathrm{O}_{3}$ forming $\mathrm{NO}_{2}$ and leading to $\mathrm{O}_{3}$ loss within the clouds. This hypothesis is supported by the modeling studies of Ott et al. (2007) and Salzmann et al. (2008), the thunderstorm observations in Ridley et al. (2006), and the laboratory data of Franzblau (1991). By the time the convective cell reaches the Panama coast, the lightning has subsided (as suggested by the WWLLN data in Table 2) and the clouds have begun to dissipate. Ozone within the clouds, therefore, may be relatively depleted compared to its prestorm values, and our balloon measurements may represent measurements at various stages of recovery as $\mathrm{NO}_{\mathrm{x}}$ photochemistry begins to favor production of $\mathrm{O}_{3}$. (2) $\mathrm{New}_{3}$ may have been produced within the cloud, as suggested by Winterrath et al. (1999), who report a $62 \%$ increase in $\mathrm{O}_{3}$ within 
thunderstorm clouds, mainly attributed to non-lightning discharges; Shlanta and Moore (1972), who found $\mathrm{O}_{3}$ levels 2.6 times higher at $6 \mathrm{~km}$ inside a cloud than pre-storm readings at the surface; and Clark and Griffing (1985), who reported $250 \%$ increases downwind of thunderstorms near Baltimore in 1980. If the dissipating cell was still producing lightning after launch, as suggested by the NPOL hourly flash estimates (Table 3), it is possible that direct production of $\mathrm{O}_{3}$ from coronal discharges occurred within the cloud, as suggested by Minschwaner et al. (2008). However, the absence of detected lightning strokes in the WWLLN record as well as the rapid dissipation of the cell as it came over land argue against the importance of this mechanism in explaining the changes observed by the sonde. (3) Mixing of air lower in ozone from near the surface lofted by the convection and air higher in $\mathrm{O}_{3}$ from above sinking near the edge of the convection may have occurred. Of course, some combination of these processes is also quite likely. Future measurements campaigns and modeling studies will be required to identify the relative importance of these processes. Nevertheless, our ozonesonde dataset provides the modeling community with new and important constraints that can be applied to future studies of $\mathrm{O}_{3}$ production associated with tropical convective cells.

Acknowledgements. Funding for this work was provided by NASA's Upper Air Research Program (M. J. Kurylo and K. W. Jucks, program managers). Thanks to the OMI team for the total column ozone data; to Robert Holzworth for the WWLLN lightning data; to William Brune (Penn State University) for the chemical box model; to Ron Cohen, Paul Wooldridge, and Anne Perring (Univ. of California, Berkeley) for the DC-8 $\mathrm{NO}$ and $\mathrm{NO}_{2}$ data; and to undergraduate students Kelsey Obenour and Danielle Slotke for helpful calculations. Special thanks to Alex Bryan and David Lutz for spending a month in the field launching our ozonesondes and to Brett Taubman (Appalatian State University) for leading the deployment of the NATIVE trailer. We also would like to thank the reviewers for their helpful comments for improving our manuscript. Finally, the authors gratefully acknowledge the NOAA Air Resources Laboratory (ARL) for the provision of the HYSPLIT transport and dispersion model and/or READY website (http://www.arl.noaa.gov/ready.php).

Edited by: T. Bertram

\section{References}

Avery, M. A., Twohy, C., McCabe, D., Joiner, J., Severance, K., Atlas, E., Blake, D., Bui, T.P., Crounse, J., Dibb, J., Diskin, G., Lawson, P., McGill, M., Rogers, D., Sachse, G., Scheuer, E., Thompson, A.M., Trepte, C., Wennberg, P., and Ziemke, J: Tropospheric ozone distribution by convection in the central American ITCZ region: Evidence from observations of ozone and clouds during the Tropical Composition, Cloud and Cli- mate Coupling Experiment, J. Geophys. Res., 115, D00J21, doi:10.1029/2009JD013450, 2010.

Beirle, S., Salzmann, M., Lawrence, M. G., and Wagner, T.: Sensitivity of satellite observations for freshly produced lightning $\mathrm{NO}_{\mathrm{x}}$, Atmos. Chem. Phys., 9, 1077-1094, doi:10.5194/acp-91077-2009, 2009.

Bhartia, P. K.: Algorithm Theoretical Basis Document, http://toms. gsfc.nasa.gov/version8/v8toms_atbd.pdf, 2007.

Boccippio, D. J.: A diagnostic analysis of the VVP single-Doppler retrieval technique, J. Atmos. Oceanic Technol., 12, 230-248, 1995.

Bucselam, E. J., Celarier, E. A., Wenig, M. O., Gleason, J. F., Veefkind, J. P., Boersma, K. F., and Brinksma, E. J.: Algorithm for $\mathrm{NO}_{2}$ vertical column retrieval from the Ozone Monitoring Instrument, IEEE T. Geosci. Remote, 44, 1245-1258, 2006.

Bucsela, E. J., Perring, A. E., Cohen, R. C., Boersma, K. F., Celarier, E. A., Gleason, J. F., Wenig, M. O., Bertram, T. H., Wooldridge, P. J., Dirksen, R., and Veefkind, J. P.: Comparison of tropospheric $\mathrm{NO}_{2}$ from in situ aircraft measurements with near-real-time and standard product data from OMI, J. Geophys. Res., 113, D16S31, doi:10.1029/2007JD008838, 2008.

Bucsela, E. J, Pickering, K. E., Huntemann, T., Cohen, R. C., Perring, A. E., Gleason, J. F. Blakeslee, R., Navano, D. V., Mora Segura, I. M., Hernández, A. P., and Laporte-Molina, S.: Lightninggenerated $\mathrm{NO}_{\mathrm{x}}$ seen by OMI during NASA's TC ${ }^{4}$ experiment, J. Geophys. Res., 115, D00J10, doi:10.1029/2009JD013118, 2010.

Celarier, E. A., Brinksma, E. J., Gleason, J. F., Veefkind, J. P., Cede, A., Herman, J. R., Ionov, D., Goutail, F., Pommeraeau, J.-P., Lambert, J.-C., van Roosendael, M., Pinardi, G., Bojkov, B., Mount, G., Spinei, E., Sander, S. P., Bucsela, E. J., Swart, D. P. J., Volten, H., Kroon, M., and Levelt, P. F.: Validation of Ozone Monitoring Instrument nitrogen dioxide columns, J. Geophys. Res., 113, D15S15, doi:10.1029/2007JD008908, 2008.

Chameides, W. L.: Effect of variable energy input on nitrogenfixation in instantaneous linear discharges, Nature, 277 (5692), 123-125, 1979.

Chameides, W. L., Stedman, D. H., Dickerson, R. R., Rusch, D. W., and Cicerone, R. J.: $\mathrm{NO}_{\mathrm{x}}$ production in lightning, J. Atmos. Sci., 34(1), 143-149, 1977.

Clark, J. F. and Griffing, G. W.: Aircraft observations of extreme ozone concentrations near thunderstorms, Atmos. Environ., 19, (7), 1175-1179, 1985.

Cooper, O. R., Stohl, A., Trainer, M., Thompson, A.M., Witte, J.C., Oltmans, S. J., Morris, G., Pickering, K. E., Crawford, J. H., Chen, G., Cohen, R. C., Bertram, T.H., Wooldridge, P., Perring, A., Brune, W.H., Merrill, J., Moody, J. L., Tarasick, D., Nedelec, P., Forbes, G., Newchurch, M. J., Schmidlin, F. J., Johnson, B. J., Turquety, S., Baughcum, S. L., Ren, X., Fehsenfeld, F.C., Meagher, J. F., Spichtinger, N., Brown, C. C., McKeen, S. A., McDermid, I. S., and Leblanc, T. : Large upper tropospheric ozone enhancements above mid-latitude North America during summer: In situ evidence from the IONS and MOZAIC ozone networks, J. Geophys. Res., 111, D24S05, doi:10.1029/2006JD007306, 2006.

Cooper, O. R., Trainer, M., Thompson, A. M., Oltmans, S. J., Tarasick, D. W., Witte, J. C., Stohl, A., Eckhardt, S., Lelieveld, J., Newchurch, M. J., Johnson, B. J., Portmann, R. W., Kalnajs, L., Dubey, M. K., Leblanc, T., McDermid, I. S., Forbes, G., Wolfe, D., Carey-Smith, T., Morris, G. A., Lefer, B., Rappenglueck, 
B., Joseph, E., Schmidlin, F., Meagher, J., Fehsenfeld, F. C., Keating, T. J., Van Curen, R. A., and Minschwaner, K.: Evidence for a recurring eastern North America upper tropospheric ozone maximum during summer, J. Geophys. Res., 112, D23304, doi:10.1029/2007JD008710, 2007.

Cummins, K. L., Murphy, M. J., Bardo, E. A., Hiscox, W. L., Pyle, R. B., and Pifer, A. E.: A combined TOA/MDF technology upgrade of the U.S. Lightning Detection Network, J. Geophys. Res., 103, D8, 9035-9044, 1998.

DeCaria, A. J., Pickering, K. E., Stenchikov, G. L., and Ott, L. E.: Lightning-generated $\mathrm{NO}_{\mathrm{x}}$ and its impact on tropospheric ozone production: A three-dimensional modeling study of a Stratospher-Troposphere Experiment: Radiation, Aerosols and Ozone (STERAO-A) thunderstorm, J. Geophys. Res., 110(D14), D14303, doi:10.1029/2004JD005556, 2005.

Dickerson, R. R., Huffman, G. J., Luke, W. T., Nunnermacker, L. J., Pickering, K. E., Leslie, A. C. D., Lindsey, C. G., Slinn, W. G. N., Kelly, T. J., Daum, P. H., Delany, A. C., Greenberg, J. P., Zimmerman, P. R., Boatman, J. F., Ray, J. D., and Stedman, D. H.: Thunderstorms: An important mechanism in the transport of air pollutants, Science, 235, 460-465, 1987.

Doherty, R. M., Stevenson, D. S., Collins, W. J., and Sanderson, M. G.: Influence of convective transport on tropospheric ozone and its precursors in a chemistry-climate model, Atmos. Chem. Phys., 5, 3205-3218, doi:10.5194/acp-5-3205-2005, 2005.

Drapcho, D. L., Sisterson, D., and Kumar, R.: Nitrogen fixation by lightning activity in a thunderstorm, Atmos. Environ., 17, 729734, 1983.

Draxler, R. R. and Rolph, G.D.: HYSPLIT (HYbrid Single-Particle Lagrangian Integrated Trajectory) Model access via NOAA ARL READY Website (http://ready.arl.noaa.gov/HYSPLIT. php), NOAA Air Resources Laboratory, Silver Spring, MD, 2010.

Duncan, B. N., Strahan, S. E., Yoshida, Y., Steenrod, S. D., and Livesey, N.: Model study of the cross-tropopause transport of biomass burning pollution, Atmos. Chem. Phys., 7, 3713-3736, doi:10.5194/acp-7-3713-2007, 2007.

Fehr, T., Holler, H., and Huntrieser, H.: Model study on production and transport of lightning-produced $\mathrm{NO}_{\mathrm{x}}$ in a EULINOX supercell storm, J. Geophys. Res., 109(D9), D09102, doi:10.1029/2003JD003935, 2004.

Fontijn, A., Sabadell, A. J., and Ronco, R. J.: Homogenous chemiluminescent measurement ofnitric oxide with ozone, Anal. Chem., 42, 575-579, 1970.

Franzblau, E.: Electrical discharges involving the formation of NO, $\mathrm{NO}_{2}, \mathrm{HNO}_{3}$, and $\mathrm{O}_{3}$, J. Geophys. Res., 96, D12, 22,337-22,345, 1991.

Futyan, J. M. and Del Genio, A. D.: Relationships between lightning and properties of convective cloud clusters, Geophys. Res. Lett. 34, L15705, doi:10.1029/2007GL030227, 2007.

Grant, W. B., Pierce, R. B., Oltmans, S. J., and Browell, E. V.: Seasonal evolution of total and gravity wave induced laminae in ozonesonde data in the tropics and subtropics, Geophys. Res. Lett., 25, 1863-1866, 1998.

Grewe, V.: The impact of climate variability on tropospheric ozone, Sci. Total Environ., 374, 167-181, 2007.

Griffing, G. W.: Ozone and oxides of nitrogen production during thunderstorms, J. Geophys. Res., 82, 943-950, 1977.

Hudman, R. C., Jacob, D. J., Turquety, S., Leibensperger, E. M.,
Murray, L.T., Wu, S., Gilliland, A. B., Avery, M., Betram, T. H., Brune, W., Cohen, R. C., Dibb, J. E., Flocke, F. M., Fried, A., Holloway, J., Newuman, J. A., Orville, R., Perring, A., Ren, X., Sachse, G. W., Singh, H. B., Swanson, A., and Wooldridge, P. J. Surface and lightning sources of nitrogen oxides over the United States: Magnitudes, chemical evolution, and outflow, J. Geophys. Res., 112, D12S05, doi:10.1029/2006JD007912, 2007.

Huntrieser, H., Schumann, U., Schlager, H., Höller, H., Giez, A., Betz, H.-D., Brunner, D., Forster, C., Pinto Jr., O., and Calheiros, R.: Lightning activity in Brazilian thunderstorms during TROCCINOX: implications for $\mathrm{NO}_{\mathrm{x}}$ production, Atmos. Chem. Phys., 8, 921-953, doi:10.5194/acp-8-921-2008, 2008.

Jenkin, M. E., Saunders, S. M., and Pilling, M. J.: The tropospheric degradation of volatile organic compounds: a protocol for mechanism development, Atmos. Environ., 31, 81-104, 1997.

Jenkins, G. S., Camara, M., and Ndiaye, S. A.: Observational evidence of enhanced middle/upper tropospheric ozone via convective processes over the equatorial tropical Atlantic during the summer of 2006, Geophys. Res. Lett., 35, L12806, doi:10.1029/2008GL033954, 2008.

Koike, M., Kondo, Y., Kita, K., Takegawa, N., Nishi, N., Kashihara, T., Kawakami, S., Kudoh, S., Blake, D., Shirai, T., Liley, B., Ko, M., Miyazaki, Y., Kawaski, Z., and Ogawa, T.: Measurements of reactive nitrogen produced by tropical thunderstorms during BIBLE-C, J. Geophys. Res., 112, D18304, doi:10.1029/2006JD008193, 2007.

Komhyr, W. D.: Operations Handbook: Ozone measurements to $40 \mathrm{~km}$ altitude with mode $4 \mathrm{~A}$ electrochemical concentration cell (ECC) ozonesondes (used with 1680-Mhz radiosondes), NOAA Technical Memorandum ERLARL-149, 1986.

Komhyr, W. D., Barnes, R. A., Brothers, G. B., Lathrop, J. A., and Opperman, D. P.: Electrochemical concentration cell performance evaluation during STOIC, J. Geophys. Res., 100, 92319244, 1995.

Kroening, J. and Ney, E.: Atmospheric Ozone, J. Geophys. Res., 67(5), 1867-1875, 1962.

Lawrence, M. G., Chameides, W. L., Kasibhatla, P. S., Levy, II, H. and Moxim, W.: Lightning and atmospheric chemistry: the rate of atmospheric NO production, 189-202, in: Handbook of Atmospheric Electrodynamics, Vol. I, edited by: Volland, H., CRC Press, Inc., Boca Raton, USA, 1995.

Lawrence, M. G., von Kuhlmann, R., Salzmann, M., and Rasch, P. J.: The balance of effects of deep convective mixing on tropospheric ozone, Geophys. Res. Lett., 30, 1940, doi:10.1029/2003GL017644, 2003.

Lay, E. H., Rodger, C. J., Holzworth, R. H, Jacobson, A. R., Suszcynsky, D. M., Thomas, J. N., and Brundell, J. B.: World-wide lightning location network: improvements in global detection efficiency and estimated stroke energy, Fourth Conference on the Meteorological Applications of Lightning Data, American Meteorological Society, Phoenix, AZ, 2009.

Levelt, P. F., Hilsenrath, E., Leppelmeier, G. W., van den Oord, G. B. J., Bhartia, P. K., Tamminen, J., de Haan, J. F., and Veefkind, J. P.: Science objectives of the Ozone Monitoring Instrument, IEEE Trans Geo. Rem. Sens., 44(5), 1199-1208, 2006.

Levelt, P. F., van den Oord, G. B. J., Dobber, M. R., Malkki, A., Visser, H., deVries, J., Stammes, P., Lundell, J. O. V., and Saari, H.: The Ozone Monitoring Instrument, IEEE Trans Geo. Rem. Sens., 44(5), 1093-1101, 2006. 
Lelieveld, J. and Crutzen, P. J.: Role of deep cloud convection in the ozone budget of the troposphere, Science, 264, 1759-1761, 1994.

Levine, J. S., Rogowski, R. S., Gregory, G. L., Howell, W. E., and Fishman, J.: Simultaneous measurements of $\mathrm{NO}_{\mathrm{x}}, \mathrm{NO}$, and $\mathrm{O} 3$ production in a laboratory discharge: Atmospheric implications, Geophys. Res. Lett., 8, 4, 357-360, 1981.

Lin, X., Trainer, M., and Liu, S.C.: On the nonlinearity of tropospheric ozone production, J. Geophys. Res., 93, 15,879-15,888, 1988.

Martin, R. V., Sauvage, B., Folkins, I., Sioris, C. E., Boone, C., Bernath, P., and Ziemke, J.: Space-based constraints on the production of nitric oxide by lightning, J. Geophys. Res., 112, D09309, doi:10.1029/2006JD007831, 2007.

McGill, M. J., Li, L., Hart, W. D., Heymsfield, G. M., Hlavka, D. L., Racette, P. E., Tian, L., Vaughan, M. A., and Winker, D. M.: Combined lidar-radar remote sensing: Initial results from CRYSTAL-FACE, J. Geophys. Res., 109, D07203, doi:10.1029/2003JD004030, 2004.

McPeters, R. D., Labow, G. J., and Johnson, B. J.: A satellitederived ozone climatology for balloonsonde estimation of total column ozone, J. Geophys. Res., 102(D7), 8875-8886, 1997.

McPeters, R., Kroon, M., Labow, G., Brinksma, E., Balis, D., Petropavlovskikh, I., Veefkind, J. P., Bhartia, P. K., and Levelt, P. F.: Validation of the Aura Ozone Monitoring Instrument total column ozone product, J. Geophys. Res., 113, D15S14, doi:10.1029/2007JD008802, 2008.

Minschwaner, K., Kalnajs, L. E., Dubey, M. K., Avallone, L. M., Sawaengphokai, P. C., Edens, H. E., and Winn, W. P.: Observation of enhanced ozone in an electrically active storm over Socorro, NM: Implications for ozone production from corona discharges, J. Geophys. Res., 113, D17208, doi:10.1029/2007JD009500, 2008.

Morris, G. A.: Explaining an oscillating weather balloon with a thermodynamic model, Am. J. Phys., to be submitted, 2011.

Noxon, J. F.: Atmospheric nitrogen fixation by lightning, Geophys. Res. Lett., 3, 8, 463-465, 1976.

Orville, R. E.: Ozone production during thunderstorms, measured by the absorption of ultraviolet radiation from lightning, J. Geophys. Res., 72, 14, 3557-3561, 1967.

Ott, L. E., Pickering, K. E., Stenchikov, G. L., Huntrieser, H., and Schumann, U.: Effects of lightning $\mathrm{NO}_{\mathrm{x}}$ production during the 21 July European Lightning Nitrogen Oxides Project storm studied with a three-dimensional cloud-scale chemical transport model, J. Geophys. Res., 112, D05307, doi:10.1029/2006JD007365, 2007.

Ott, L., Pickering, K. E., Stenchikov, G., Allen, D., DeCaria, A., Ridley, B., Lin, R.-F., Lang, S., and Tao, W.-K.: Production of lightning $\mathrm{NO}_{\mathrm{x}}$ and its vertical distribution calculated from threedimensional cloud-scale chemical transport model simulations, J. Geophys. Res., 115, D04301, doi:10.1029/2009JD011880, 2010.

Pearson, R. W. and Stedman, D. H.: Instrumentation for fast response ozone measurements from aircraft, Atmos. Tech., 12, 5155, 1980.

Peyrous, R. and Lapeyre, R.-M.: Gaseous products created by electrical discharges in the atmosphere and condensation nuclei resulting from gaseous phase reactions, Atmos. Environ., 16, 5, 959-968, 1982.

Pfister, G. G., Emmons, L. K., Hess, P. G., Lamarque, J.-F.,
Thompson, A. M., Yorks, J. E.: Analysis of the Summer 2004 Ozone Budget over North America using IONS Observations and MOZART-4 Simulations, J. Geophys. Res., 113, D23306, doi:10.1029/2008JD010190, 2008.

Pickering, K. E., Thompson, A. M., Dickerson, R. R., Luke, W. T., McNamara, D. P., Greenberg, J. P., and Zimmerman, P. R.: Model calculations of tropospheric ozone production potential following observed convective events, J. Geophys. Res., 95, 14,049-14,062, 1990.

Pickering, K. E., Thompson, A. M., Wang, Y., Tao, W.-K., McNamara, D. P., Kirchhoff, V. W. J. H., Heikes, B. G., Sachse, G. W., Bradshaw, J. D., Gregory, G. L., and Blake, D. R.: Convective transport of biomass burning emissions over Brazil during TRACE-A, J. Geophys. Res., 101, 23,993-24,012, 1996.

Pickering, K. E., Wang, Y., Tao, W.-K., Price, C., and Müller, J.F.: Vertical distributions of lightning $\mathrm{NO}_{\mathrm{x}}$ for use in regiona and global chemical transport models, J. Geophys. Res., 103(D23), 31,203-31,216, 1998.

Pickering, K. E., Huntrieser, H., and Schumann, U.: Chapter 26: Lightning and $\mathrm{NO}_{\mathrm{x}}$ production in global models in Lightning: Principles, Instruments and Applications, edited by: Schumann, U., and Laroche, P., doi:10.1007/978-1-4020-9079-0-26, 2009.

Pierce, E. T.: Latitudinal variation of lightning parameters, J. Appl. Meteor., 9, 194-195, 1970.

Prentice, S. A. and Mackerras, D.: The ratio of cloud to cloudground lightning flashes in thunderstorms, J. Appl. Meteor., 16, 545-549, 1977.

Price, C. and Rind, D.: A simple lightning parameterization for calculating global lightning distributions, J. Geophys. Res., 97(D9), 9919-9933, 1992.

Price, C., Penner, J., and Prather, M.: $\mathrm{NO}_{\mathrm{x}}$ from lightning 1: Global distribution based on lightning physics, J. Geophys. Res., 102(D5), 5929-5941, 1997.

Ridley, B., Ott, L., Pickering, K., Emmons, L., Montzka, D., Weinheimer, A., Knapp, D., Grahek, F., Li, L., Heymsfield, G., McGill, M., Kucera, P., Mahoney, M.J., Baumgardner, D., Schultz, M., and Brasseur, G.: Florida thunderstorms: A faucet of reactive nitrogen to the upper troposphere, J. Geophys. Res., 109, D17305, doi:10.1029/2004JD004769, 2004.

Ridley, B. A., Avery, M. A., Plant, J. V., Vay, S. A., Montzka, D. D., Weinheimer, A. J., Knapp, D. J., Dye, J. E., and Richard, E. C.: Sampling of chemical constituents in electrically active convective systems: Results and cautions, J. Atmos. Chem., 54, 1-20, doi:10.1007/s10874-005-9007-5, 2006.

Rodger, C. J., Werner, S., Brundell, J. B., Lay, E. H., Thomson, N. R., Holzworth, R. H., and Dowden, R. L.: Detection efficiency of the VLF World-Wide Lightning Location Network (WWLLN): initial case study, Ann. Geophys., 24, 3197-3214, 2006.

Salzmann, M., Lawrence, M. G., Phillips, V. T. J., and Donner, L. J.: Cloud system resolving model study of the roles of deep convection for photo-chemistry in the TOGA COARE/CEPEX region, Atmos. Chem. Phys., 8, 2741-2757, doi:10.5194/acp-82741-2008, 2008.

Sander, S. P., Friedl, R. R., Ravishankara, A. R., Golden, D. M., Kolb, C. E., Kurylo, M. J., Molina, M. J., Moortgat, G. K., Keller-Rudek, H. J., Finlayson-Pitts, B., Wine, P. H., Huie, R. E., and Orkin, V. L.: Chemical Kinetics and Photochemical Data for Use in Atmospheric Studies, Evaluation Number 15, JPL Publication 06-2, NASA Jet Propulsion Laboratory, Pasadena, 
California, 2006.

Schlanta, A. and Moore, C.B.: Ozone and point discharge measurements in thunderclouds, J. Geophys. Res., 77, 24, 4500-4510, 1972.

Schoeberl, M. R. and Sparling, L.: Trajectory modeling, in Diagnostic Tools in Atmospheric Physics, Proceedings of the International School of Physics "Enrico Fermi", 124, edited by: Fiocco, G. and Visconti,G., 289-306, IOS Press, Washington DC, 1995.

Schoeberl, M. R., Douglass, A. R., Hilsenrath, E., Bhartia, P. K., Beer, R., Waters, J. W. Gunson, M. R., Froidevaux, L., Gille, J. C., Barnett, J. J., Levelt, P. E., and DeCola, P.: Overview of the EOS Aura Mission, IEEE T. Geosci. Remote, 44(5), 1066-1074, 2006.

Schumann, U. and Huntrieser, H.: The global lightning-induced nitrogen oxides source, Atmos. Chem. Phys., 7, 3823-3907, doi:10.5194/acp-7-3823-2007, 2007.

Shon, Z.-H., Madronich, S., Song, S.-K., Flocke, F. M., Knapp, D. J., Anderson, R. S., Shetter, R. E., Cantrell, C. A., Hall, S. R., and Tie, X.: Characteristics of the NO-NO2-O 3 system in different chemical regimes during the MIRAGE-Mex field campaign, Atmos. Chem. Phys., 8, 7153-7164, doi:10.5194/acp-8-7153-2008, 2008.

Skamarock, W. C., Dye, J. E., Defer, E., Barth, M. C., Stith, J. L., Ridley, B. A., and Baumann, K.: Observational- and modeling-based budget of lightning produced $\mathrm{NO}_{\mathrm{x}}$ in a continental thunderstorm, J. Geophys. Res., 108(D10), 4305, doi:10.1029/2002JD002163, 2003.

Smit, H.G., Straeter, W., Johnson, B. J., Oltmans, S. J., Davis, J., Tarasick, D. W., Hoegger, B., Stubi, R., Schmidlin, F. J., Northam, T., Thompson, A. M., Witte, J. C., Boyd, I., and Posny, F.: Assessment of the performance of ECC-ozonesondes under quasi-flight conditions in the environmental simulation chamber: Insights from the Jülich Ozone Sonde Intercomparison Experiment (JOSIE), J. Geophys. Res., 112, D19306, doi:10.1029/2006JD007308, 2007.

Stockwell, W. R., Kirchner, F., Kuhn, M., and Seefeld, S.: A new mechanism for regional atmospheric chemistry modeling, J. Geophys. Res., 102, 25,847-825,879, 1997.

Theisen, C. J., Kucera, P. A., and Poellot, M. R.: A study of relationships between tropical thunderstorm properties and corresponding anvil cloud characteristics, J. Meteor. and Climate, 48(9), 1882-1901, 2009.

Thompson, A. M., Tao, W.-K., Pickering, K. E., Scala, J. R., and Simpson, J.: Tropical deep convection and ozone formation, Bull. Amer. Met. Soc., 78, 1,043-1,054, 1997.

Thompson, A. M., Witte, J. C., McPeters, R. D., Oltmans, S. J., Schmidlin, F. J., Logan, J. A., Fujiwara, M., Kirchhoff, V. W. J. H., Posny, F., Coetzee, G. J. R., Hoegger, B., Kawakami, S., Ogawa, T., Johnson, B. J., Vömel, H., and Labow, G.: Southern Hemisphere Additional Ozonesondes (SHADOZ) 1998-2000 tropical ozone climatology 1. Comparison with Total Ozone Mapping Spectrometer (TOMS) and ground-based measurements, J. Geophys. Res., 108(D2), 8238, doi:10.1029/2001JD000967, 2003.

Thompson, A. M., Stone, J. B., Witte, J. C., Miller, S. K., Pierce, R. B., Chatfield, R. B., Oltmans, S. J., Cooper, O. R., Loucks, A. L., Taubman, B. F., Johnson, B. J., Joseph, E., Kucsera, T. L., Merrill, J. T., Morris, G. A., Hersey, S., Forbes, G., Newchurch, M. J., Schmidlin, F.J., Tarasick, D.W., Thouret, V., and Cam- mas, J.-P.: IONS (INTEX Ozonesonde Network Study, 2004), 1. Summertime UT/LS (Upper Troposphere/Lower Stratosphere) ozone over northeastern North America, J. Geophys. Res., 112, D12S12, doi:10.1029/2006JD007441, 2007a.

Thompson, A. M., Stone, J. B., Witte, J. C., Miller, S. K., Oltmans, S. J., Kucsera, T. L., Ross, K. L., Pickering, K. E., Merrill, J. T., Forbes, G., Tarasick, D. W., Joseph, E., Schmidlin, F. J., McMillan, W. W., Warner, J., Hintsa, E. J., and Johnson, J. E: Intercontinental Transport Experiment Ozonesonde Network Study (IONS, 2004): 2. Tropospheric Ozone Budgets and Variability over Northeastern North America, J. Geophys. Res., 112, D12S13, doi:10.1029/2006JD007670, 2007b.

Thompson, A. M., Witte, J. C., Smit, H. G. J., Oltmans, S. J., Johnson, J. J., Kirchhoff, V. W. J. H., and Schmidlin, F. J.: Southern Hemisphere Additional Ozonesondes (SHADOZ) 1998-2004 tropical ozone climatology. 3. Instrumentation, Station Variability, Evaluation with Simulated Flight Profiles, J. Geophys. Res., 112, D03304, doi:10.1029/ 2005JD007042, 2007c.

Thompson, A. M., Yorks, J. E., Miller, S. K., Witte, J. C., Dougherty, K. M., Morris, G. A., Baumgardner, D., Ladino, L., and Rappenglück, B.: Tropospheric ozone sources and wave activity over Mexico City and Houston during MILAGRO/Intercontinental Transport Experiment (INTEX-B) Ozonesonde Network Study, 2006 (IONS-06), Atmos. Chem. Phys., 8, 5113-5125, doi:10.5194/acp-8-5113-2008, 2008.

Thompson, A. M., MacFarlane, A. M., Morris, G. A., Yorks, J. E., Miller, S. K., Taubman, B. F., Verver, G., Vomel, H., Avery, M. A., Hair, J. W., Diskin, G. S., Browell, E. V., Canossa, J. V., Kucsera, T. L., Klich, C. A., and Hlavka, D. L.: Convective and wave signatures in ozone profiles over the equatorial Americas: Views from $\mathrm{TC}^{4}$ (2007) and SHADOZ, J. Geophys. Res., 115, D00J23, doi:10.1029/2009JD012909, 2010.

Thornton, J. A., Wooldridge, P. J., and Cohen, R. C.: Atmospheric $\mathrm{NO}_{2}$ : In situ laser-induced fluorescence detection at parts per trillion mixing ratios, Anal. Chem., 72, 528-539, 2000.

Toon, O. B., Starr, D. O., Jensen, E. J., Newman, P. A., Platnick, S., Schoeberl, M. R., Wennberg, P. O., Wofsy, S. C., Kurylo, M. J., Maring, H., Jucks, K. W., Craig, M. S., Vasques, M. F., Pfister, L., Rosenlof, K. H., Selkirk, H. B., Colarco, P. R., Kawa, S. R., Mace, G. G., Minnis, P., and Pickering, K. E.: Tropical Composition, Clouds, and Climate Coupling (TC4) Overview, J. Geophys. Res., 115, D00J04, doi:10.1029/2009JD013073, 2010.

Wenig, M. O., Cede, A. M., Bucsela, E. J. Celarier, E. A., Boersma, K. F., Veefkind, J. P., Brinksma, E. J., Gleason, J. F., and Herman, J. R.: Validation of OMI tropospheric $\mathrm{NO}_{2}$ column densities using direct-sun mode Brewer measurements at NASA Goddard Space Flight Center, J. Geophys. Res., 113, D16S45, doi:10.1029/2007JD008988, 2008.

Winterrath, T., Kurosu, T. P., Richter, A., and Burrows, J. P.: Enhanced $\mathrm{O}_{3}$ and $\mathrm{NO}_{2}$ in thunderstorm clouds: Convection or production, Geophys. Res. Lett., 26, 9, 1291-1294, 1999.

Wood, E. C., Herndon, S. C., Onasch, T. B., Kroll, J. H., Canagaratna, M. R., Kolb, C. E., Worsnop, D. R., Neuman, J. A., Seila, R., Zavala, M., and Knighton, W. B.: A case study of ozone production, nitrogen oxides, and the radical budget in Mexico City, Atmos. Chem. Phys., 9, 2499-2516, doi:10.5194/acp-9-2499-2009, 2009.

Zaveri, R. A., Berkowitz, C. M., Kleinman, L. I., Springston, S. R., Doskey, P. V., Lonneman, W. A., and Spicer, C. W.: Ozone 
production efficiency and $\mathrm{NO}_{\mathrm{x}}$ depletion in an urban plume: Interpretation of field observations and implications for evaluating $\mathrm{O}_{3}-\mathrm{NO}_{\mathrm{x}}-\mathrm{VOC}$ sensitivity, J. Geophys. Res., 108(D19), doi:10.1029/2002JD003144, 2003.
Zhang, R., Tie, X., and Bond, D. W.: Impacts of anthropogenic and natural $\mathrm{NO}_{\mathrm{X}}$ sources over the U.S. on tropospheric chemistry, Proc. Natl. Acad. Sci. U. S. A., 100, 1505-1509, doi:10.1073/pnas.252763799, 2003. 